\title{
Iron organic speciation during the LOHAFEX experiment: Iron ligands release under biomass control by copepod grazing
}

\author{
Luis M. Laglera ${ }^{\mathrm{a}, \mathrm{b}, *}$, A. Tovar-Sanchez ${ }^{\mathrm{c}}$, C.F. Sukekava ${ }^{\mathrm{a}}$, H. Naik ${ }^{\mathrm{d}}$, S.W.A. Naqvi ${ }^{\mathrm{d}}$, \\ D.A. Wolf-Gladrow ${ }^{\mathrm{e}}$ \\ ${ }^{a}$ FI-TRACE, Departamento de Química, Universidad de las Islas Baleares, Palma, Balearic Islands 07122, Spain \\ ${ }^{\mathrm{b}}$ Laboratori Interdisciplinar sobre Canvi Climátic. Universidad de las Islas Baleares, Palma, Balearic Islands 07122, Spain \\ ${ }^{\mathrm{c}}$ Department of Ecology and Coastal Management, Andalusian Institute for Marine Science, ICMAN (CSIC), Campus Universitario Río San Pedro, Puerto Real, Cádiz, \\ Spain \\ ${ }^{\mathrm{d}}$ National Institute of Oceanography, Dona Paula, Goa, India \\ ${ }^{\mathrm{e}}$ Alfred-Wegener-Institut Helmholtz Zentrum für Polar- und Meeresforschung, Am Handelshafen 12, 27570 Bremerhaven, Germany
}

\section{A R T I C L E I N F O}

\section{Keywords:}

LOHAFEX

Iron cycling

Iron speciation

Grazing

Southern Ocean

Iron fertilization

\begin{abstract}
A B S T R A C T
The LOHAFEX iron fertilization experiment consisted in the fertilization of the closed core of a cyclonic eddy located south of the Antarctic Polar Front in the Atlantic sector of the Southern Ocean. This eddy was characterized by high nitrate and low silicate concentrations. Despite a 2.5 fold increase of the chlorophyll-a (Chl-a) concentrations, the composition of the biological community did not change. Phytoplankton biomass was mostly formed by small autotrophic flagellates whereas zooplankton biomass was mostly comprised by the large copepod Calanus simillimus. Efficient recycling of copepod fecal pellets (the main component of the downward flux of organic matter) in the upper 100-150 m of the water column prevented any significant deep export of particulate organic carbon (POC).

Before fertilization, dissolved iron (DFe) concentrations in the upper $200 \mathrm{~m}$ were low, but not depleted, at $\sim 0.2 \mathrm{nM}$. High DFe concentrations appeared scattered from day 14 onwards as a result of the grazing activity. A second fertilization on day 21 had no significant effect on the DFe and Chl-a standing stocks. Work with unfiltered samples using different acidification protocols revealed that, by midway of LOHAFEX, rapid recycling of iron-replenished copepod fecal pellets explained the source of bioavailable iron that prolonged the duration of the bloom for many weeks.

Here we present the evolution of the organic speciation of iron in the upper $200 \mathrm{~m}$ of the water column during LOHAFEX by a Competing Ligand Equilibrium method using voltammetry. During the first 12 days of the experiment, ligands of an affinity for iron similar to the ligands found before fertilization $\left(\log K_{\mathrm{Fe}}^{\prime}{ }_{\mathrm{L}} \sim 11.9\right)$ accumulated in fertilized waters mostly in the upper $80 \mathrm{~m}$ (from $\sim 1 \mathrm{nM}$ to $\sim 2.5 \mathrm{nM}$ ). The restriction of ligand accumulation to the depth of Chl-a penetration points to exudation by the growing autotrophic population as the initial source of ligands. From day 5 onwards, we found in many samples a new class of ligands $\left(\mathrm{L}_{1}\right)$ characterized by a significant higher conditional stability constant than the background complexation ( $\log \mathrm{K}_{\mathrm{Fe} \text { L1 }}^{\prime} \sim 12.9$ ). During the middle section of the experiment (days 12 to 25) the accumulation of overall ligands and specifically $L_{1}$, reached an upper limit in surface waters (at $\sim 3 \mathrm{nM}$ ). Overall ligands and $\mathrm{L}_{1}$ accumulation was also observed below the mixed layer depth indicating that grazing was the process behind ligand release. During the last 10 days of the experiment ligands kept accumulating in deep waters but suffered a small decrease in the upper $50 \mathrm{~m}$ of the water column caused by the vanishing of $\mathrm{L}_{1}$. Ligand removal restricted to the euphotic layer was probably caused by photodegradation. A high correlation between [DFe] and $\left[\mathrm{L}_{1}\right]$ suggested that recycled iron (released during grazing and copepod fecal pellet cycling) was in the form of FeL $\mathrm{C}_{1}$ complexes. We hypothesize that the iron binding ligands released to the dissolved phase during LOHAFEX were mostly photosensitive intracellular ligands rapidly degraded in extracellular conditions (e.g.: pigments). Sloppy feeding by copepods and recycling of cells and cellular material in copepod fecal pellets caused the transfer of particulate ligands to the dissolved phase as zooplankton built up as a response to the blooming community.
\end{abstract}

\footnotetext{
* Corresponding author at: FI-TRACE, Departamento de Química, Universidad de las Islas Baleares, Palma, Balearic Islands 07122, Spain.

E-mail address: luis.laglera@uib.es (L.M. Laglera).
} 


\section{Introduction}

The LOHAFEX experiment was the latest ocean iron fertilization (OIF) experiment carried out to investigate the biochemical effects of iron additions in high nutrient-low chlorophyll (HNLC) waters. Every previous OIF experiment had confirmed the "iron hypothesis" suggested by Martin (Martin, 1990): limiting concentrations of the micronutrient iron in surface waters severely constrain primary productivity in HNLC areas (which account for nearly $1 / 3$ of the global ocean). OIFs and similar experiments carried out in HNLC regions subjected to natural iron sources have been essential for shaping our understanding of biogeochemical processes in open ocean waters. Ecosystem alterations in HNLC areas enabled the assessment of the modulating role played by other factors, such as temperature, water mass dynamics, concentration of silicic acid, depth of the mixed layer, and the composition of grazing zooplankton (Assmy et al., 2013; Boyd et al., 2007; de Baar et al., 2005; Smetacek et al., 2012; Smetacek and Naqvi, 2008; Tsuda et al., 2007).

The inorganic speciation of iron in seawater is dominated by the highly insoluble species $\mathrm{Fe}(\mathrm{OH})_{3}{ }^{0}(\mathrm{~s})$ which limits inorganic iron solubility at tens of picomol L $\mathrm{L}^{-1}$ (Liu and Millero, 2002). Iron solubility is enhanced to levels that can sustain aquatic organisms by i) the ubiquitious presence of organic ligands that preclude the formation of inorganic aggregates (oxyhydroxides) by complexation (Gledhill and Buck, 2012; Rue and Bruland, 1995; van den Berg, 1995) and ii) the formation of transitory concentrations of the more soluble species $\mathrm{Fe}^{\mathrm{II}}$ (King et al., 1995; Kondo and Moffett, 2015).

The organic complexation of trace elements in natural waters is usually determined by Competing Ligand Equilibrium-Adsorptive Cathodic Stripping Voltammetry (CLE-AdCSV) which is based on the addition of an artificial ligand to the sample that competes with natural ligands and forms an electroactive complex with the element of interest (van den Berg, 1984, 1995). The technique provides the concentration of the bulk of organic ligands in solution (so called complexing capacity) and their conditional stability constant for a specific trace element. Thus, the contribution of the artificial ligand to the organic speciation of the trace element can be removed and the concentration of the free trace element originally present in the sample can be back calculated. Since natural iron binding ligands are generally found in ocean waters significantly in excess of dissolved iron (DFe), organic complexation constitutes commonly about $99 \%$ of DFe (Gledhill and Buck, 2012; Shaked and Lis, 2012). Despite of recent major advances in chromatographic techniques, we still have a very poor understanding about the nature and origin of natural ligands (Boiteau et al., 2016; Mawji et al., 2008). Various authors have stressed the role of diverse groups of natural binding molecules: siderophores and their degradation products (Boiteau et al., 2016; Hunter and Boyd, 2007; Mawji et al., 2008; Velasquez et al., 2016), humic substances (HS) (Krachler et al., 2015; Laglera and van den Berg, 2009), molecules with the heme group (Gledhill et al., 2013; Hogle et al., 2014) and phytoplankton exopolysaccharides (Hassler et al., 2011). We still do not have the possibility to quantify the individual contribution of those substances to the pool of organic ligands, let alone determine which one of those is actually complexing iron in ocean waters. At this stage we can only hypothesize their nature based on the comparison of conditional stability constants assuming equilibrium conditions.

Information about the concentration of iron ligands in the Atlantic Sector of the Southern Ocean is scarce. Previous studies have shown great variability with concentrations spanning one order of magnitude from 0.2 to $2.6 \mathrm{nM}$ (Boye et al., 2001; Croot et al., 2004; Thuróczy et al., 2011). In the few cases in which the concentration of iron ligands were monitored during OIF experiments (EISENEX, SEED II and Iron-Ex II), their concentration increased rapidly (1-2 days) and significantly (3-6 fold) (Boye et al., 2005; Kondo et al., 2008; Rue and Bruland, 1997). In all 3 papers it was hypothesized that partial stabilization of the added iron as inorganic colloids (i.e. colloids that are not measured because they are not solubilized by the competing artificial ligand) could have contributed to the ligand concentration. This is based on i) a biological response of that magnitude in such a short period was unlikely and ii) sometimes DFe concentrations were determined above the ligand concentration. However, contradicting this observation, repeated fertilizations of the patch, that should have accumulated inert colloids in the water column, did not result in increased ligand concentrations (Boye et al., 2005). Another consistent observation is that ligands decreased rapidly after the initial accumulation, but after successive fertilizations, ligands above the mixed layer depth (MLD) stabilized at levels slightly higher than initial concentrations (Boye et al., 2005; Kondo et al., 2008). During the OIF SOIREE it was suggested that the observed stabilization of DFe concentrations following refertilization of the bloom was caused by the accumulation of organic ligands (Bowie et al., 2001).

Here we describe and discuss the changes that the organic speciation of iron underwent in the upper $200 \mathrm{~m}$ of the water column during LOHAFEX. This article complements our previous work on the temporal evolution of iron partitioning during LOHAFEX where we demonstrated the major role of copepod fecal pellets in the dissolved/particulate partitioning and recycling of iron during the experiment (Laglera et al., 2017).

\subsection{The LOHAFEX experiment}

The Indo-German OIF experiment LOHAFEX was carried out by releasing 2 tons of iron in the form of dissolved iron sulfate in the closed core of a cyclonic eddy located south of the Antarctic Polar Front in the southwestern Atlantic sector of the Southern Ocean during the austral summer of 2009 (on board the R/V Polarstern, ANT-XXV/3) $\left(48^{\circ} \mathrm{S}\right.$, $15^{\circ} \mathrm{W}$, Fig. 1A). A more detailed description of the experiment settings and its evolution can be found elsewhere (Ebersbach et al., 2014; Martin et al., 2013; Mazzocchi et al., 2009; Smetacek and Naqvi, 2010). Briefly, $300 \mathrm{~km}^{2}$ were fertilized at the center of an eddy characterized by: moderate Chl-a concentration ( $0.4-0.5 \mathrm{mg} \mathrm{Chl-a} \mathrm{m}^{-3}$ ), low but nondepleted DFe concentrations $(\sim 0.2 \mathrm{nM})$ and low silicate concentrations $(<1 \mu \mathrm{M})$ in the mixed layer. Due to the scale of the LOHAFEX experiment, 2 to 3 days were required to fertilize the whole area and repositioning the ship at the center of the created patch. This prevented any data collection in the first $48 \mathrm{~h}$ of the experiment. During the following 39 days, the location and extent of the moving patch together with many biological and chemical variables were monitored. On day 21 , after an observed slight decrease of the Chl-a concentration, another 2 tons of iron was released along longitudinal transects across the patch.

After rotating clockwise inside the eddy, at the time of departure the fertilized patch had been elongated due to the lateral effect of a nearby anticyclone (Fig. 1A). Dilution of the "hot spot" of the patch was moderate during the first half of the experiment (about $50 \%$ by day 20 ) but as the patch started to "sense" the eddy boundaries, dilution increased substantially (about $80 \%$ by day 39) (Martin et al., 2013).

\subsection{Major biochemical changes caused by iron supply}

The effect of fertilization was evident from i) a substantial increase of the Chl-a standing stock (Figs. 1B and S1) (from 39 to $106 \mathrm{mg} \mathrm{Chl-a}$ $\mathrm{m}^{-2}$ on day 16 and never below $\sim 70 \mathrm{mg}$ Chl-a $\mathrm{m}^{-2}$ for the rest of the experiment despite patch dilution and fragmentation), ii) an increase of the net community production (NCP) from $\sim 0$ to $\sim 30-40 \mathrm{mmol} \mathrm{C} \mathrm{m}^{-2}$ $\mathrm{d}^{-1}$ from day 5 to day 23 and iii) an increase of the photosynthetic quantum efficiency $(F v / F m)$ ratio from an initial $\sim 0.33$ to $0.4-0.5$ for the rest of the experiment (Martin et al., 2013). This increase of the Fv/ $\mathrm{Fm}$ ratio in fertilized waters indicated a permanent relief from iron limitation during the experiment. Low silicate concentrations kept diatom numbers low and the increase in biomass was not accompanied by any significant change of the pre-fertilization composition of the plankton community (Mazzocchi et al., 2009; Schulz et al., 2018; Thiele 


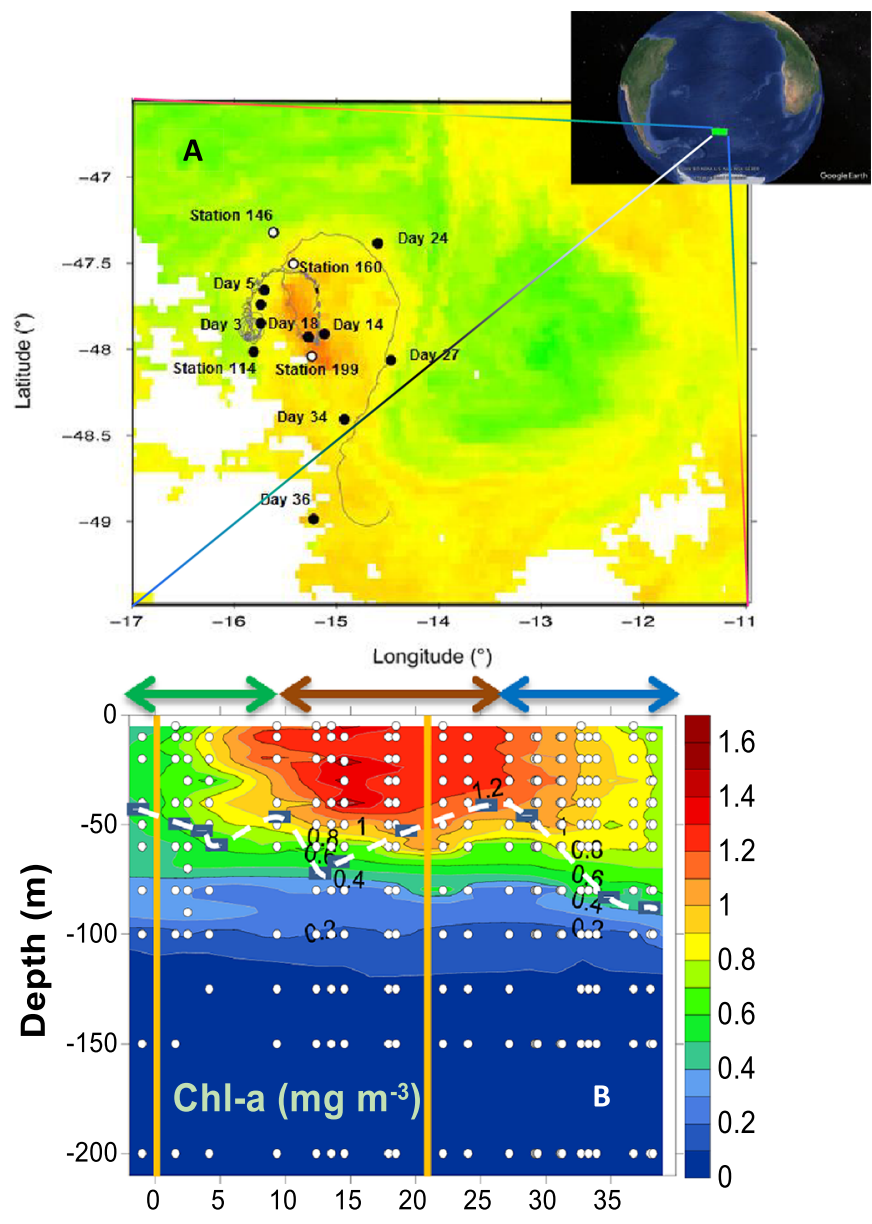

Time since 1st fertilization (days)

Fig. 1. Top: Globe map (Google Earth) showing the location of the LOHAFEX experiment. Middle: Chlorophyll-a concentrations including the fertilized patch (irregular red area inside) from a satellite image obtained 2 weeks after the initial fertilization (27 January 2009, Station 114). The gray lines show the trajectories of the buoys deployed to track the fertilized patch. Dates mark the position of stations in fertilized waters and stations in non fertilized waters are marked with the station code (see Table 1 for further details). Bottom: Temporal evolution of Chl-a concentrations in the upper $200 \mathrm{~m}$ of the water column of the fertilized patch during the LOHAFEX experiment. The different stages of the experiment (growth, grazing and dilution) are indicated by the colored double arrows. The white dashed line indicates the mixed layer depth (MLD). The two fertilizations are indicated by the two vertical orange lines. (For interpretation of the references to color in this figure legend, the reader is referred to the web version of this article.)

et al., 2012; Thiele et al., 2014). Therefore, there was no community gradient across the patch boundaries. Bacterial and archaeal plankton numbers were barely affected by the fertilization (Thiele et al., 2012). Nanoflagellates (Phaeocystis-like species) and coccoid cells $(<10 \mu \mathrm{m})$ dominated the phytoplankton biomass and were kept under control by the increasing number of the large copepod Calanus simillimus $(\sim 30,000$ individuals $\mathrm{m}^{-2}$ with a diurnal migration down to $200 \mathrm{~m}$ ) (Mazzocchi et al., 2009). Copepod numbers were themselves controlled by predation by the carnivorous amphipod Themisto gaudichaudii (Mazzocchi et al., 2009).

Mid way of the experiment there was a mild accumulation of biomass throughout the selected eddy. The biomass increment is indicated by increased Chl-a concentrations at the selected OUT stations (max-

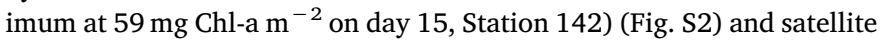
images (Fig. 1A for the Chl-a image obtained 18 days into the experiment) (Laglera et al., 2017). This natural biomass growth yielded a spatial and temporal continuity of the structure of the biological community inside and outside the fertilized patch. As a result, many biological and chemical variables did not show gradients across the patch boundaries during the duration of the experiment: e.g.: numbers of bacterioplankton (Thiele et al., 2012), numbers of Calanus copepods (Mazzocchi et al., 2009), copepod fecal pellet standing stocks, DFe concentrations (Laglera et al., 2017), and, as we will show below, the concentration of iron organic ligands.

A remarkable outcome of the LOHAFEX experiment was the lack of significant export of particulate organic carbon (POC) from the blooming patch. Nearly all sinking particles (mostly comprised of $C$. simillimus fecal pellets) were remineralized within the upper $100-150 \mathrm{~m}$ (Ebersbach et al., 2014; Martin et al., 2013). Copepod fecal pellet recycling was favored by copepod feeding habits that not only include preying on smaller plankton but feeding on fecal material (including their own) via coprophagy (pellet ingestion), coprorhexy (pellet fragmentation) or coprochaly (pellet peeling) (Gonzalez and Smetacek, 1994; Iversen and Poulsen, 2007; Jansen et al., 2007; Noji et al., 1991).

\subsection{LOHAFEX experiment stages}

For practical purposes we have divided the time evolution of the LOHAFEX experiment into three stages after consideration of the evolution of key biological and chemical parameters (Martin et al., 2013; Mazzocchi et al., 2009; Smetacek and Naqvi, 2010): 1) an initial stage characterized by a steady increase of Chl-a concentrations and NCP, and consumption of nutrients $\left(\mathrm{NO}_{3}{ }^{-}, \mathrm{PO}_{4}{ }^{3-}\right)$ labeled as the growth stage. This initial stage extended from the fertilization up to day 10 (Fig. 1B). 2) A second stage referred as the grazing stage where nitrate consumption continued but Chl-a concentrations and NCP levelled off due to the grazing pressure exerted by large copepods. This stage extended from day 10 to day 24. 3) During the last two weeks (days 25-37) of the experiment we observed a moderate decrease of the Chl-a concentration (despite substantial patch dilution), a decrease of NCP back to zero about day 27, stable nutrient concentrations, and relaxation of the grazing pressure. We refer to this last stage as the dilution stage.

\subsection{Iron cycling during LOHAFEX}

The temporal evolution of iron partitioning in the upper $200 \mathrm{~m}$ of the water column during LOHAFEX has been presented in a previous article (Laglera et al., 2017). Since iron cycling is imbricated with changes in its organic speciation we present a brief recapitulation here. We observed that DFe concentrations in the upper $200 \mathrm{~m}$ were barely changed by the two fertilizations (both equivalent to $120 \mu \mathrm{mol} \mathrm{Fe}{ }^{-2}$, i.e.: $2.4 \mathrm{nM}$ over the upper $50 \mathrm{~m}$, the pre-fertilization MLD). However, after 14 days, coinciding with the peaking of Chl-a concentrations, DFe profiles became patchily distributed and with increasing concentrations down to $200 \mathrm{~m}$ (Figs. 2 and 3A). This distribution is indicative of transfer from the particulate to the dissolved fraction. Copepod fecal pellet counting and analysis of their iron content allowed us to determine the contribution of copepod fecal pellets to the standing stocks of particulate iron. We estimated that after the second fertilization, the percentages of DFe, iron in copepod fecal pellets and iron in the rest of particulate material (biological and mineral phases) in fertilized waters in the upper $80 \mathrm{~m}$ were approximately constant at 25,40 and $35 \%$, respectively (equivalent approximately to concentrations of $0.6,1.1$ and $1.0 \mathrm{nM} \mathrm{Fe}$, respectively). Increased and patchy DFe concentration determined during the last two stages of the experiment would be mainly the result of "sloppy feeding" (the process where approximately $50 \%$ of food is dispersed as DOC during prey crushing before ingestion) (Møller et al., 2003). Here, we assume that iron binding ligands included in cells and fecal pellets, are spilled in a similar percentage. The iron content of $C$. simillimus fecal pellet was $\sim 5$ fold higher if the copepod had been captured in fertilized waters $(0.041 \pm 0.019$ vs 

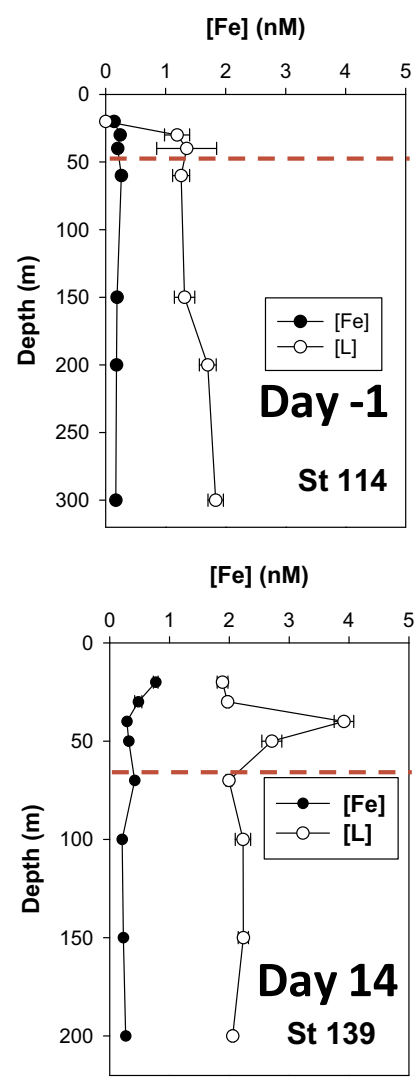

[Fe] (nM)

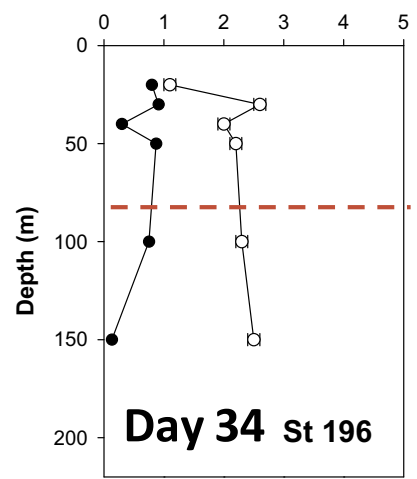

[Fe] (nM)

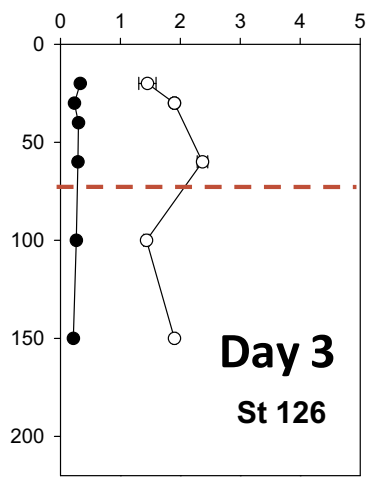

[Fe] (nM)

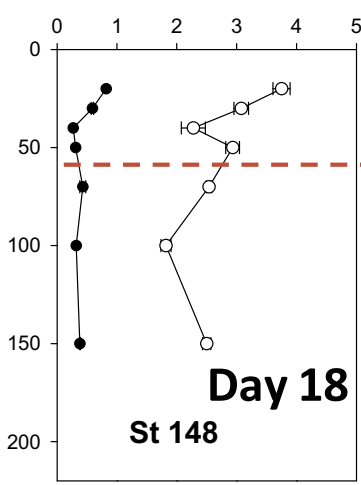

[Fe] (nM)

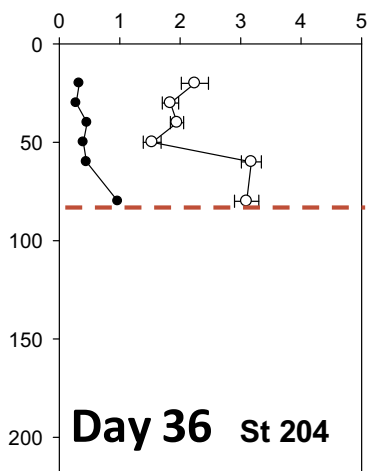

[Fe] (nM)

[Fe] (nM)

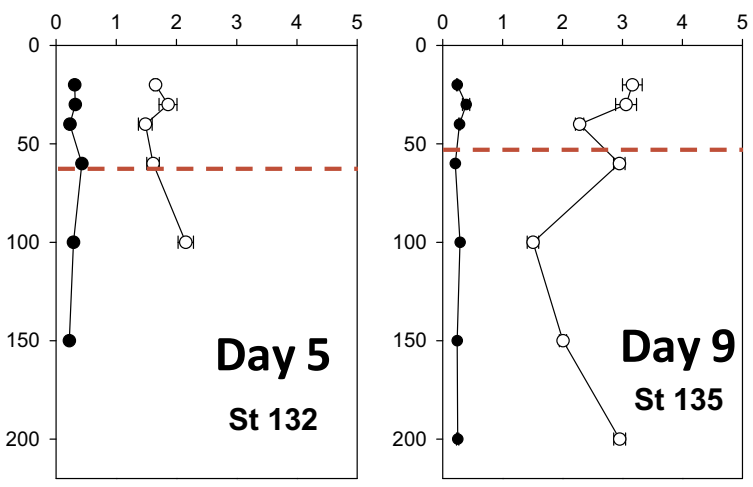

[Fe] (nM)

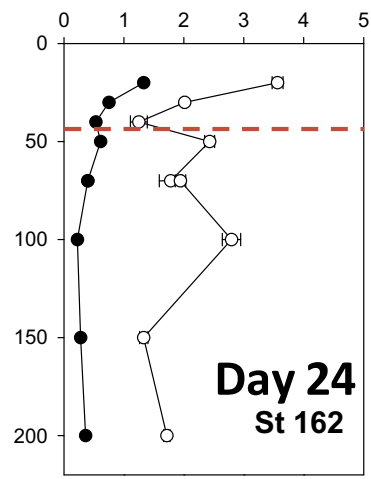

[Fe] (nM)

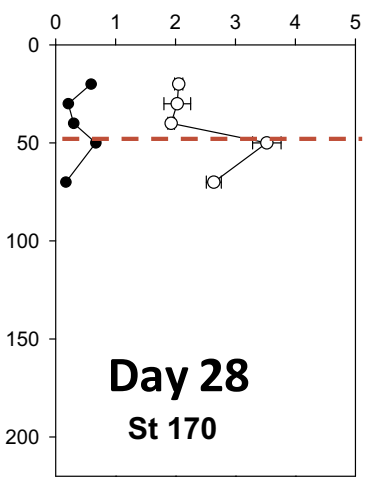

[Fe] (nM)
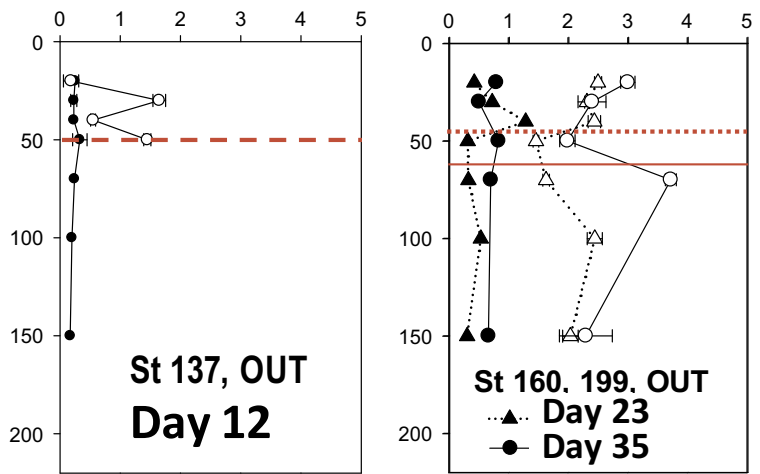

Fig. 2. Vertical distribution of DFe and iron binding ligands (1 type of ligand model) measured in the upper water column during the LOHAFEX experiment. The dashed red lines indicate the MLD (details in (Martin et al., 2013). Note the different depth scale at Station 114, day -1. Station 137 (day 12 ) sampling started in fertilized waters, however, it is probable that the ship drifted from fertilized waters during sample collection. DFe and L concentrations found in two stations sampled in non fertilized waters are shown in the last plot (solid line, MLD at station 199). (For interpretation of the references to color in this figure legend, the reader is referred to the web version of this article.)

$0.006 \pm 0.009 \mathrm{nmol} \mathrm{Fe} \mathrm{pellet}^{-1}$ ). Lower Chl-a concentrations in nonfertilized waters were not explained by DFe concentrations (similar to fertilized water) but by the lower iron concentrations found in copepod fecal pellets. Rapid recycling of iron-loaded copepod fecal pellets in the upper $100 \mathrm{~m}$ of the water column provided the iron required for the longevity of the LOHAFEX bloom.

\section{Materials and methods}

\subsection{Trace clean sampling}

A detailed description of sampling and iron analysis protocols can be found elsewhere (Laglera et al., 2017). Iron speciation samples were collected immediately after collection of partitioning samples from the same Go-Flo bottles. Briefly, samples from the water column, usually down to $200 \mathrm{~m}$, were collected in Teflon-coated $5 \mathrm{~L}$ Go-Flo bottles mounted in an epoxy coated aluminum frame (all from General Oceanics). Speciation samples were collected at 16 stations (Table 1): one before fertilization, 13 in fertilized waters during the experiment and 2 in non-fertilized waters. Once on deck, the Go-Flo bottles were moved to the laboratory and fixed to a vertical stand inside an overpressurized particle-free plastic "bubble". Seawater was filtered through polycarbonate sterile capsules $(0.2 \mu \mathrm{m}$, Sartobran 300$)$ after pressurizing the Go-Flo bottle head space with $0.2 \mu \mathrm{m}$ filtered high purity nitrogen. Samples for iron speciation were stored in $500 \mathrm{~mL}$ LDPE bottles, immediately frozen and stored in freezers for months before being thawed overnight the day before analysis. 

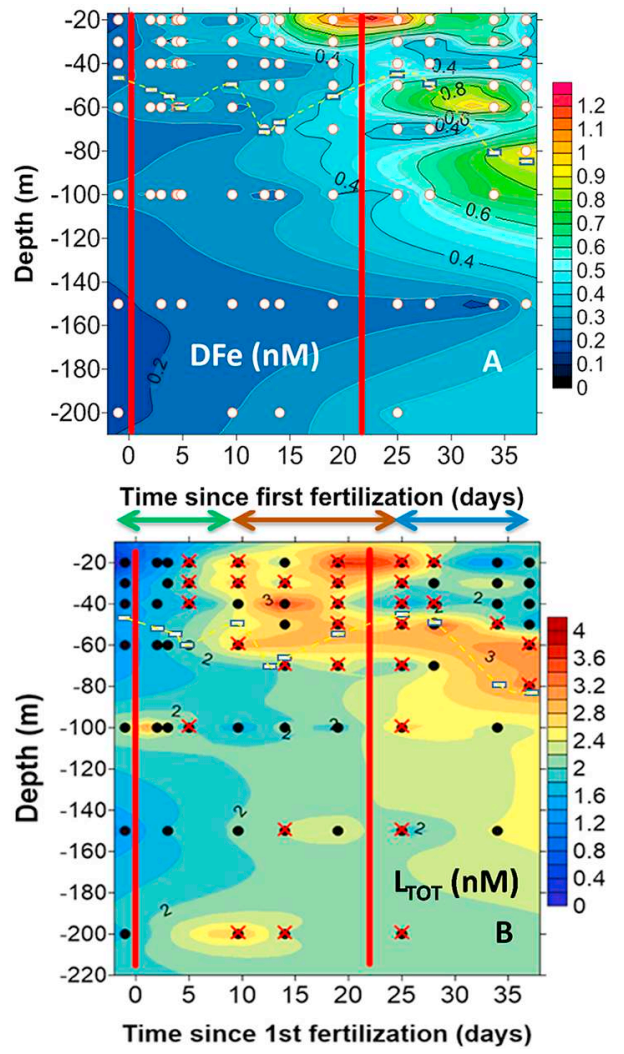

Fig. 3. Time course of the concentration of dissolved iron (A) and iron binding ligands (B) in the upper $200 \mathrm{~m}$ of the water column of the fertilized patch during the LOHAFEX experiment. The red lines indicate the two fertilization events. The different stages of the experiment are indicated with color coded double ended arrows. The mixed layer depth, indicated with white rectangles linked by a dashed yellow line was around $50-60 \mathrm{~m}$ in the first $3-4$ weeks and deepened to around $80 \mathrm{~m}$ thereafter. Red crosses in B indicate those samples where it was possible to resolve two types of ligands (see Table 3 and Section 3.4 for detailed information). All concentrations in nM. (For interpretation of the references to color in this figure legend, the reader is referred to the web version of this article.)

Table 1

Summary of LOHAFEX stations where the water column was sampled for the analysis of iron speciation.

\begin{tabular}{llll}
\hline Station & Days after 1st fertiliz. & Days after 2nd fertiliz. & Features \\
\hline 114 & -1 & - & Initial conditions \\
121 & 2 & - & IN \\
126 & 3 & - & IN \\
132 & 4.9 & - & IN \\
135 & 9 & - & IN \\
137 & 13 & - & Intended IN \\
139 & 14 & - & IN \\
148 & 18 & - & IN \\
160 & 23 & 2 & OUT \\
162 & 24 & 3 & IN \\
170 & 27 & 6 & IN \\
196 & 34 & 13 & IN \\
199 & 35 & 14 & OUT \\
204 & 36 & 15 & IN \\
\hline
\end{tabular}

\subsection{Equipment and reagents}

Electrochemical analyses were performed in a 663 VA stand (Metrohm AG) provided with a hanging mercury drop electrode (HMDE), a glassy carbon counter electrode, and an $\mathrm{Ag} / \mathrm{AgCl}$ reference electrode. Signal collection and peak treatment was executed with a $\mu$ Autolab voltammeter and the GPES software (Eco Chemie B.V.).
Ultrapure water was purified using an Elix/Milli-Q apparatus (Millipore). Ammonia (UltraTrace, Sigma) was of the maximum commercially available purity. Iron standards were dilutions in acidified Milli-Q water $\left(\mathrm{pH}_{\mathrm{NBS}}=2.0\right)$ of an atomic absorption spectrometry standard solution (BDH). The ligand added to form an electrolabile complex with iron was 2,3-dihydroxynaphthalene (DHN, Merck) that was dissolved in bi-distilled methanol at a concentration of $20 \mathrm{mM}$. The catalytic/buffering solution required for the method was a combined solution of $0.4 \mathrm{M}$ piperazine- $N, N^{\prime}$-bis-(2-hydroxypropanesulfonic) acid (POPSO, Sigma-Aldrich) and $0.1 \mathrm{M}$ potassium bromate (AnalaR, BDH) brought to $\mathrm{pH}_{\mathrm{NBS}} 8.1$ with ammonia. Trace metal impurities were removed after repeating twice the following procedure: addition of a $\mathrm{MnO}_{2}$ suspension, swirling during $24 \mathrm{~h}$ to promote the adsorption of iron impurities to the colloid, and gravity filtration $(0.2 \mu \mathrm{m})$ to remove $\mathrm{MnO}_{2}$. The iron contamination from all reagents (DHN $+\mathrm{BrO}_{3}+$ POPSO) (analytical blank) was determined by tripling their individual concentration during the analysis of ultrapure water and was found to be $0.06 \mathrm{nM}$.

\subsection{Dissolved iron}

The methodology followed for the analysis of the concentration of dissolved iron has been described in detail in a previous paper (Laglera et al., 2017). Briefly, two different analytical techniques were used: onboard Adsorptive Cathodic Stripping Voltammetry (AdCSV) as in (Laglera et al., 2013b) in an effort to contribute to the tracking of the patch and lab-based Inductively Coupled Plasma-Mass Spectroscopy (ICP-MS) as in (Tovar-Sánchez, 2012) in stored samples. In a subset of samples kept for analysis by both methods we obtained a robust agreement (see (Laglera et al., 2017) for more details).

\subsection{Iron speciation}

Iron speciation was determined after iron titration by CLE-AdCSV in the presence of $\mathrm{DHN}, \mathrm{BrO}_{3}{ }^{-}$(catalytic reagent) and POPSO (buffer). A detailed description of the analytical protocol can be found elsewhere (Laglera et al., 2011; van den Berg, 2006). Briefly, a $120 \mathrm{~mL}$ sample was mixed in a LDPE bottle with DHN (final concentration $0.5 \mu \mathrm{M}$ DHN, log $\left.\alpha_{\mathrm{Fe}^{\prime} \text {-DHN }}=2.81\right)$ and split into 12 aliquots placed in $30 \mathrm{~mL}$ polycarbonate containers. Nine of the containers were spiked with increasing iron concentrations in the range from 0.3 to $18 \mathrm{nM}$, and all of them were left to equilibrate overnight in a refrigerator (typically for $16 \mathrm{~h}$ ). The first aliquot was used to condition the electrochemical cell and the result of this analysis was not considered. Two hours before analysis the samples were allowed to reach room temperature in the dark. After addition of a POPSO/borate mixed solution, AdCSV analysis gave the concentration of iron sequestered by DHN (known as labile iron) at increasing DFe concentrations (titration data). The percentages of labile iron with respect to DFe in aliquots not spiked with additional Fe can be found in Table 2 .

The treatment of titration data allows the determination of the concentration of natural ligands with the ability to complex iron ([L]) and the conditional stability constant of their complexes $\left(\mathrm{K}_{\mathrm{Fe}}^{\prime} \mathrm{L}\right)$.The underlying mathematical background of how $[\mathrm{L}]$ and $\mathrm{K}_{\mathrm{Fe}^{\prime} \mathrm{L}}$ are obtained can be found elsewhere (Gledhill and van den Berg, 1994) and it has been critically discussed several times (Gerringa et al., 2014; Laglera et al., 2013a; Pižeta et al., 2015). Briefly, the titration data (labile versus total iron concentrations) were plotted and the final straight part of the plot was used to calculate the sensitivity. This sensitivity was not corrected following iterative methods (Turoczy and Sherwood, 1997) or fitted combined with the complexing parameters (Sander et al., 2011) for two reasons: i) maximum iron additions were considerably in excess of the complexing capacity (4 to 20 fold) (Laglera et al., 2013a) producing data sets with very good linearity in their final section and ii) when we tried the effect of the two referred corrections, solutions clearly spread out due to the introduction of several clear 
Table 2

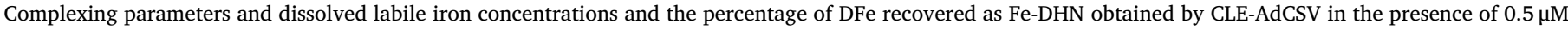

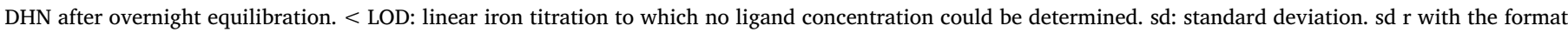

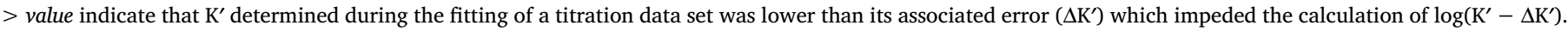
In those cases, we used $\log \left(\mathrm{K}^{\prime}+\Delta \mathrm{K}^{\prime}\right)$ as an approach to the minimum error associated to the calculation of $\log \left(\mathrm{K}^{\prime}\right)$.

\begin{tabular}{|c|c|c|c|c|c|c|c|c|c|c|}
\hline Station & Exp. days & Depth (m) & {$[\mathrm{Fe}]_{\mathrm{diss}}(\mathrm{nM})$} & [L] (nM) & sd & $\log \mathrm{K}^{\prime}$ & sd & $\log \alpha_{\mathrm{FeL}}$ & {$[\mathrm{Fe}]_{\mathrm{lab}}(\mathrm{nM})$} & $\%$ labile \\
\hline 114 & -1 & 20 & 0.14 & $<$ LOD & - & - & - & - & 0.22 & $157 \%$ \\
\hline 114 & -1 & 30 & 0.20 & 1.2 & 0.2 & 11.85 & 0.21 & 2.80 & 0.17 & $56 \%$ \\
\hline 114 & -1 & 40 & 0.26 & 1.3 & 0.5 & 11.69 & 0.50 & 2.72 & 0.17 & $66 \%$ \\
\hline 114 & -1 & 60 & 0.25 & 1.3 & 0.1 & 11.55 & 0.21 & 2.55 & 0.22 & $84 \%$ \\
\hline 114 & -1 & 100 & 0.27 & 2.0 & 0.2 & 11.82 & 0.19 & 3.24 & 0.10 & $36 \%$ \\
\hline 114 & -1 & 150 & 0.32 & 1.3 & 0.2 & 11.25 & 0.17 & 2.25 & 0.27 & $81 \%$ \\
\hline 114 & -1 & 200 & 0.22 & 1.7 & 0.1 & 11.49 & 0.19 & 2.66 & 0.22 & $90 \%$ \\
\hline 114 & -1 & 300 & 0.17 & 1.8 & 0.1 & 11.69 & 0.21 & 2.88 & 0.15 & $50 \%$ \\
\hline 121 & 2 & 20 & 0.32 & 1.9 & 0.1 & 11.60 & 0.14 & 2.79 & 0.22 & $66 \%$ \\
\hline 121 & 2 & 40 & 0.30 & 1.9 & 0.1 & 11.56 & 0.14 & 2.76 & 0.20 & $64 \%$ \\
\hline 121 & 2 & 60 & 0.28 & 1.8 & 0.2 & 11.68 & 0.23 & 2.86 & 0.19 & $64 \%$ \\
\hline 121 & 2 & 100 & 0.24 & 3.9 & 0.1 & 11.77 & 0.08 & 3.33 & 0.08 & $32 \%$ \\
\hline 126 & 3 & 20 & 0.33 & 1.5 & 0.1 & 11.65 & 0.35 & 2.69 & 0.24 & $69 \%$ \\
\hline 126 & 3 & 30 & 0.23 & 1.9 & 0.1 & 12.44 & 0.28 & 3.66 & 0.03 & $13 \%$ \\
\hline 126 & 3 & 60 & 0.30 & 2.4 & 0.1 & 12.24 & 0.65 & 3.55 & 0.06 & $20 \%$ \\
\hline 126 & 3 & 100 & 0.29 & 1.4 & 0.1 & 12.27 & 0.28 & 3.34 & 0.05 & $17 \%$ \\
\hline 126 & 3 & 150 & 0.26 & 1.9 & 0.1 & 12.12 & 0.10 & 3.35 & 0.05 & $24 \%$ \\
\hline 132 & 5 & 20 & 0.31 & 1.7 & 0.1 & 12.17 & 0.22 & 3.29 & 0.05 & $16 \%$ \\
\hline 132 & 5 & 30 & 0.32 & 1.9 & 0.1 & 12.05 & 0.76 & 3.24 & 0.07 & $20 \%$ \\
\hline 132 & 5 & 40 & 0.23 & 1.5 & 0.1 & 11.81 & 0.46 & 2.91 & 0.06 & $26 \%$ \\
\hline 132 & 5 & 60 & 0.43 & 1.6 & 0.1 & 11.87 & 0.29 & 2.95 & 0.12 & $28 \%$ \\
\hline 132 & 5 & 100 & 0.29 & 2.2 & 0.1 & 11.91 & 0.37 & 3.18 & 0.04 & $12 \%$ \\
\hline 135 & 9 & 20 & 0.24 & 3.2 & 0.2 & 11.82 & 0.21 & 3.28 & 0.04 & $16 \%$ \\
\hline 135 & 9 & 30 & 0.39 & 3.1 & 0.2 & 11.71 & 0.14 & 3.13 & 0.05 & $12 \%$ \\
\hline 135 & 9 & 40 & 0.28 & 2.3 & 0.1 & 11.81 & 0.12 & 3.11 & 0.12 & $40 \%$ \\
\hline 135 & 9 & 60 & 0.21 & 2.9 & 0.1 & 12.01 & 0.16 & 3.45 & 0.01 & $7 \%$ \\
\hline 135 & 9 & 100 & 0.29 & 1.5 & 0.1 & 11.59 & 0.18 & 2.67 & 0.18 & $58 \%$ \\
\hline 135 & 9 & 150 & 0.24 & 2.0 & 0.1 & 11.63 & 0.07 & 2.87 & 0.11 & $42 \%$ \\
\hline 135 & 9 & 200 & 0.25 & 3.0 & 0.1 & 12.28 & 0.37 & 3.71 & 0.02 & $7 \%$ \\
\hline $137^{*}$ & 13 & 20 & 0.25 & 0.18 & 0.1 & 11.27 & $>0.46$ & 0.30 & 0.21 & $81 \% \mathrm{~s}$ \\
\hline $137^{*}$ & 13 & 30 & 0.23 & 1.6 & 0.1 & 11.88 & 0.44 & 3.03 & 0.19 & $80 \%$ \\
\hline $137^{*}$ & 13 & 40 & 0.23 & 0.55 & 0.1 & 12.38 & $>0.44$ & 2.87 & 0.08 & $34 \%$ \\
\hline $137^{*}$ & 13 & 50 & 0.33 & 1.5 & 0.1 & 12.34 & 0.80 & 3.38 & 0.05 & $16 \%$ \\
\hline 139 & 14 & 20 & 0.77 & 1.9 & 0.1 & 12.13 & 0.70 & 3.18 & 0.18 & $23 \%$ \\
\hline 139 & 14 & 30 & 0.48 & 2.0 & 0.1 & 12.20 & 0.13 & 3.37 & 0.07 & $14 \%$ \\
\hline 139 & 14 & 40 & 0.29 & 3.9 & 0.2 & 11.63 & 0.10 & 3.18 & 0.13 & $45 \%$ \\
\hline 139 & 14 & 50 & 0.32 & 2.7 & 0.2 & 11.34 & 0.08 & 2.72 & 0.19 & $57 \%$ \\
\hline 139 & 14 & 70 & 0.42 & 2.0 & 0.1 & 11.95 & 0.12 & 3.14 & 0.19 & $41 \%$ \\
\hline 139 & 14 & 100 & 0.21 & 2.2 & 0.1 & 11.87 & 0.30 & 3.17 & 0.08 & $37 \%$ \\
\hline 139 & 14 & 150 & 0.23 & 2.2 & 0.1 & 12.11 & 0.35 & 3.41 & 0.03 & $11 \%$ \\
\hline 139 & 14 & 200 & 0.27 & 2.1 & 0.1 & 12.45 & 0.22 & 3.70 & 0.03 & $13 \%$ \\
\hline 148 & 19 & 20 & 0.82 & 3.7 & 0.1 & 11.85 & 0.13 & 3.32 & 0.07 & $9 \%$ \\
\hline 148 & 19 & 30 & 0.59 & 3.1 & 0.1 & 11.75 & 0.11 & 3.14 & 0.03 & $6 \%$ \\
\hline 148 & 19 & 40 & 0.27 & 2.3 & 0.2 & 11.32 & 0.10 & 2.62 & 0.13 & $46 \%$ \\
\hline 148 & 19 & 50 & 0.31 & 2.9 & 0.1 & 12.02 & 0.26 & 3.44 & 0.03 & $10 \%$ \\
\hline 148 & 19 & 70 & 0.44 & 2.5 & 0.1 & 11.94 & 0.09 & 3.26 & 0.07 & $16 \%$ \\
\hline 148 & 19 & 100 & 0.32 & 1.8 & 0.1 & 12.08 & 0.49 & 3.26 & 0.09 & $26 \%$ \\
\hline 148 & 19 & 150 & 0.38 & 2.5 & 0.1 & 12.20 & 0.27 & 3.52 & 0.08 & $20 \%$ \\
\hline 162 & 25 & 20 & 1.33 & 3.6 & 0.1 & 11.80 & 0.09 & 3.16 & 0.24 & $18 \%$ \\
\hline 162 & 25 & 30 & 0.75 & 2.0 & 0.1 & 12.22 & 0.14 & 3.33 & 0.11 & $14 \%$ \\
\hline 162 & 25 & 40 & 0.53 & 1.6 & 0.1 & 11.88 & 0.43 & 2.88 & 0.21 & $33 \%$ \\
\hline 162 & 25 & 50 & 0.61 & 2.4 & 0.1 & 11.97 & 0.21 & 3.23 & 0.09 & $14 \%$ \\
\hline 162 & 25 & 70 & 0.40 & 1.7 & 0.1 & 11.79 & 0.29 & 3.01 & 0.09 & $22 \%$ \\
\hline 162 & 25 & 70 & 0.40 & 1.9 & 0.1 & 12.18 & 0.53 & 3.37 & 0.07 & $17 \%$ \\
\hline 162 & 25 & 100 & 0.22 & 2.7 & 0.2 & 11.59 & 0.14 & 2.97 & 0.08 & $22 \%$ \\
\hline 162 & 25 & 150 & 0.28 & 1.8 & 0.1 & 11.67 & 0.15 & 2.84 & 0.09 & $32 \%$ \\
\hline 162 & 25 & 200 & 0.36 & 2.0 & 0.1 & 11.92 & 0.10 & 3.13 & 0.08 & $22 \%$ \\
\hline 170 & 28 & 20 & 0.59 & 2.1 & 0.1 & 11.92 & 0.18 & 3.08 & 0.14 & $23 \%$ \\
\hline 170 & 28 & 30 & 0.21 & 2.0 & 0.2 & 11.25 & 0.13 & 2.51 & 0.15 & $70 \%$ \\
\hline 170 & 28 & 40 & 0.3 & 1.9 & 0.1 & 11.85 & 0.12 & 3.06 & 0.08 & $27 \%$ \\
\hline 170 & 28 & 50 & 0.67 & 3.5 & 0.2 & 11.72 & 0.22 & 3.18 & 0.18 & $26 \%$ \\
\hline 170 & 28 & 70 & 0.17 & 2.6 & 0.1 & 11.50 & 0.09 & 2.89 & 0.16 & $88 \%$ \\
\hline 196 & 34 & 20 & 0.80 & 1.1 & 0.1 & 12.03 & 0.83 & 2.49 & 0.24 & $30 \%$ \\
\hline 196 & 34 & 30 & 0.91 & 2.6 & 0.1 & 12.16 & 0.59 & 3.39 & 0.18 & $20 \%$ \\
\hline 196 & 34 & 40 & 0.30 & 2.0 & 0.1 & 11.64 & 0.15 & 2.87 & 0.22 & $72 \%$ \\
\hline 196 & 34 & 50 & 0.87 & 2.2 & 0.1 & 12.10 & 0.27 & 3.23 & 0.05 & $6 \%$ \\
\hline 196 & 34 & 100 & 0.75 & 2.3 & 0.1 & 12.27 & 0.63 & 3.47 & 0.11 & $15 \%$ \\
\hline 196 & 34 & 150 & 0.13 & 2.5 & 0.1 & 12.21 & 0.26 & 3.58 & 0.06 & $42 \%$ \\
\hline 204 & 37 & 20 & 0.33 & 2.2 & 0.2 & 11.46 & 0.19 & 2.74 & 0.19 & $57 \%$ \\
\hline 204 & 37 & 30 & 0.28 & 1.8 & 0.1 & 11.67 & 0.18 & 2.86 & 0.17 & $58 \%$ \\
\hline 204 & 37 & 40 & 0.46 & 1.9 & 0.1 & 11.95 & 0.39 & 3.12 & 0.15 & $32 \%$ \\
\hline
\end{tabular}

(continued on next page) 
Table 2 (continued)

\begin{tabular}{|c|c|c|c|c|c|c|c|c|c|c|}
\hline Station & Exp. days & Depth (m) & {$[\mathrm{Fe}]_{\mathrm{diss}}(\mathrm{nM})$} & [L] $(\mathrm{nM})$ & sd & $\log \mathrm{K}^{\prime}$ & sd & $\log \alpha_{\mathrm{FeL}}$ & {$[\mathrm{Fe}]_{\mathrm{lab}}(\mathrm{nM})$} & $\%$ labile \\
\hline 204 & 37 & 50 & 0.4 & 1.5 & 0.1 & 11.86 & 0.88 & 2.91 & 0.16 & $39 \%$ \\
\hline 204 & 37 & 60 & 0.45 & 3.2 & 0.2 & 11.97 & 0.27 & 3.40 & 0.06 & $12 \%$ \\
\hline 204 & 37 & 80 & 0.97 & 3.1 & 0.2 & 12.48 & 0.19 & 3.97 & 0.07 & $7 \%$ \\
\hline \multicolumn{11}{|c|}{ OUT stations } \\
\hline 160 & 22 & 20 & 0.78 & 3.0 & 0.1 & 12.18 & 0.38 & 3.53 & 0.07 & $9 \%$ \\
\hline 160 & 22 & 30 & 0.49 & 2.4 & 0.2 & 11.86 & 0.67 & 3.15 & 0.08 & $17 \%$ \\
\hline 160 & 22 & 50 & 0.82 & 2.0 & 0.1 & 12.04 & 0.93 & 3.10 & 0.09 & $11 \%$ \\
\hline 160 & 22 & 70 & 0.69 & 3.7 & 0.1 & 12.25 & 0.21 & 3.73 & 0.02 & $2 \%$ \\
\hline 160 & 22 & 150 & 0.65 & 2.3 & 0.4 & 11.33 & 0.32 & 2.54 & 0.23 & $35 \%$ \\
\hline 199 & 35 & 20 & 0.43 & 2.5 & 0.1 & 11.63 & 0.06 & 2.94 & 0.17 & $39 \%$ \\
\hline 199 & 35 & 30 & 0.73 & 2.3 & 0.0 & 12.10 & 0.10 & 3.30 & 0.14 & $19 \%$ \\
\hline 199 & 35 & 40 & 1.29 & 2.4 & 0.1 & 12.12 & 0.55 & 3.18 & 0.36 & $28 \%$ \\
\hline 199 & 35 & 50 & 0.32 & 1.5 & 0.0 & 12.17 & 0.27 & 3.22 & 0.06 & $19 \%$ \\
\hline 199 & 35 & 70 & 0.33 & 1.6 & 0.1 & 12.07 & 0.29 & 3.19 & 0.10 & $28 \%$ \\
\hline 199 & 35 & 100 & 0.54 & 2.4 & 0.1 & 12.54 & 0.17 & 3.82 & 0.03 & $5 \%$ \\
\hline
\end{tabular}

overestimations of the sensitivity. Those same problems with the correction of sensitivity have been identified in prior work with model and "real" copper titration data (Laglera et al., 2013a).

Scatchard and van den Berg/Ruzic linearizing plots of data for titrations (Ruzic, 1982; Sposito, 1982; van den Berg, 1982) showed straight lines for all samples collected at the initial stages of the experiment; these results indicate that only a unique class of ligands could be defined. As the experiment progressed and [L] increased, many sets of titration data showed Scatchard plots that were bent (i.e. they diverged from a straight line); this is indicative of the emergence of a different class of ligand $\left(\mathrm{L}_{1}\right)$ with an affinity for iron $\left(\mathrm{K}_{\mathrm{Fe}_{\mathrm{L} 1}^{\prime} 1}^{\prime}\right)$ significantly higher than the background initial ligands that we will refer in this case as $\mathrm{L}_{2}\left(\mathrm{~K}_{\mathrm{Fe}}^{\prime} \mathrm{L} 2\right)$. Given this heterogeneity, calculations were repeated in those samples using a two classes of ligand model $\left(\mathrm{L}_{1} / \mathrm{K}^{\prime}{ }_{\mathrm{Fe}}^{\prime} \mathrm{L} 1\right.$ and $\mathrm{L}_{2} / \mathrm{K}_{\mathrm{Fe}}^{\prime} \mathrm{L} 2$ ). Although nonlinear fitting (Gerringa et al., 1995) was always possible for those titration plots showing linear trends, nonlinear fitting to 4 parameters became impossible for most of the curved (i.e. non-straight) plots and we decided to apply to all those data an iterative linear fitting treatment as described before (Laglera-Baquer et al., 2001; Laglera et al., 2013a). To avoid solutions from mixed methods (that confer data different statistical weights) we present here data for a one ligand class obtained with a linear fitting as described before (Ruzic, 1982; van den Berg, 1982). Complexing parameters for all samples considering one single type of ligand are presented in Table 2 whereas Table 3 shows the parameters obtained by the two types of ligands model for those samples where at least data at three different iron concentrations were clearly indicating the presence of more than one type of ligand.

Standard deviations of the complexing parameters were calculated according to the error propagation theory (Monticelli et al., 2010; Pižeta et al., 2015). As $\mathrm{K}_{\mathrm{Fe} \mathrm{L}}^{\prime}$ is presented in logarithmic units, calculated errors form an asymmetric interval (Gerringa et al., 1995). Standard deviations in Tables S1 and S2 correspond always to the wider side of the interval. When the error was higher than the parameter value, the result is that only one of the limits of the error interval can be calculated in logarithmic units. In those cases we specified with " > value" that we are presenting the side of the error interval that was not missing. This failure to produce error estimations was caused in most cases by the few titration data points that we could assign to calculate $\mathrm{L}_{1} / \log \mathrm{K}_{\mathrm{FeL} 1}^{\prime}$ (ranging from 3 to 6 ) since a minimum of 4 data points per ligand is necessary to obtain statistically sound estimates (Gerringa et al., 2014). Large errors introduce uncertainty in the study of temporal and spatial trends of complexation parameters and of their correlation with other variables. For this reason, we avoided the study of single profiles. However, grouping data in standing stocks (see below) for the study of temporal trends, and the use of our whole $\mathrm{L}_{1}$ database for correlation with other variables $\left(\mathrm{n}_{\mathrm{L} 1}=38\right)$, reduces substantially the uncertainty.

\subsection{Integrated iron stocks in the different fractions during LOHAFEX}

The evolution of ligand concentrations in seawater responds to the combined effect of many biological processes: exudation, degradation, cellular lysis, grazing, microbial activity, etcetera. The complexity provoked by the combination of those effects is reflected in incoherent profiles and spatial patchiness and interferes with the study of temporal trends. We tried to minimize the effect of patchiness by calculating standing stocks of iron and ligands integrating their concentrations over the upper $80 \mathrm{~m}$. The reason behind selecting a fixed depth at $80 \mathrm{~m}$ and not the variable MLD was presented before (Laglera et al., 2017). Briefly, we observed during LOHAFEX that many biological and chemical parameters showed strong gradients located well below the MLD (white dashed line in Fig. 1B) which is routinely calculated with standard criteria based on density gradients. Concentration gradients of Chl-a (Fig. 1A), POC (data not shown) and dissolved (Fig. 2) and particulate Fe (Laglera et al., 2017) were often found below the MLD. Based on those observations, we selected the maximum depth of Chl-a penetration at $80 \mathrm{~m}$ as integration depth (Fig. 4) in order to disentangle the effects of processes carried out by primary producers from those related to grazing and remineralization that can extend further down.

\subsection{Study of the analytical restrictions of the dihydroxynaphthalene/ bromate method for the study of iron speciation}

Earlier work (Laglera et al., 2011) showed that some CLE-AdCSV protocols (including the DHN/bromate catalytic method used here) could not resolve iron complexation by HS. Briefly, iron complexed with natural ligands must not show any electrolability since natural complexation is calculated by subtracting electrolabile iron from DFe throughout the iron titration (Gerringa et al., 2014). In the presence of bromate, the voltammetric signal of Fe-HS complexes is obtained at the same potential as the Fe-DHN peak (Laglera et al., 2011). Overlapping impedes the isolation of the signal generated by the Fe-DHN complex. Since the electrolabile fraction is overestimated, the fraction complexed by HS is underestimated to the extent that could go completely unnoticed. As a consequence, the analysis by CLE-AdCSV of UV-digested seawater in the presence of HS and DHN/bromate showed titration plots characteristic of an absence of organic complexation (Laglera et al., 2011). This limitation was verified in our analytical conditions by repeating the analysis of some samples after the addition of $0.12 \mathrm{mg} \mathrm{L}^{-1}$ Suwannee River fulvic acid (SRFA, IHSS), equivalent to an increase of the complexing capacity of $2.0 \mathrm{nM}$ (Laglera et al., 2011; Laglera and van den Berg, 2009; Yang et al., 2017) and $2 \mathrm{nM}$ desferroxamine B (DFB, SigmaAldrich) as examples of terrestrial hydrophobic ligands and biologically produced hydrophilic exudates (results given in Fig. S3 and Table S1). Another possible experimental design would have been the addition of those ligands to UV-digested seawater but this 
Table 3

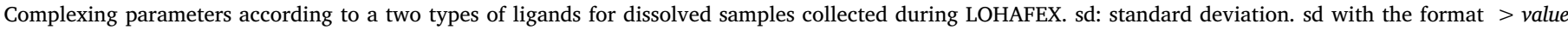

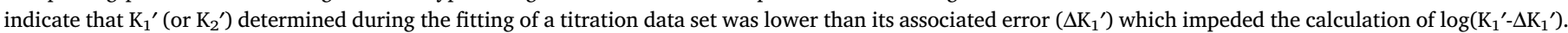

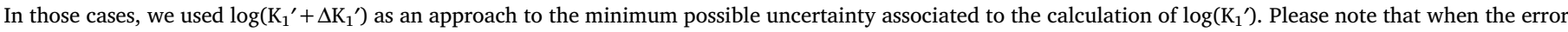
propagation theory is used on iterative linear fitting, sometimes the statistical uncertainty associated to $\mathrm{L}_{1}$ complexing parameters is substantial.

\begin{tabular}{|c|c|c|c|c|c|c|c|c|c|}
\hline Station & Depth (m) & {$\left[\mathrm{L}_{1}\right](\mathrm{nM})$} & sd & $\log K_{1}^{\prime}$ & sd & {$\left[\mathrm{L}_{2}\right](\mathrm{nM})$} & sd & $\log K_{2}^{\prime}$ & sd \\
\hline 132 & 20 & 0.45 & 0.55 & 13.02 & $>0.31$ & 1.35 & 0.14 & 11.50 & 0.27 \\
\hline 132 & 30 & 0.78 & 0.62 & 12.44 & 0.54 & 1.12 & 0.26 & 11.64 & $>0.32$ \\
\hline 132 & 40 & 0.57 & 0.66 & 12.59 & $>0.30$ & 1.16 & 0.34 & 11.10 & 0.43 \\
\hline 132 & 100 & 0.45 & 0.65 & 13.15 & $>0.35$ & 1.76 & 0.20 & 11.68 & 0.70 \\
\hline 135 & 20 & 0.38 & 0.59 & 13.14 & $>0.36$ & 3.11 & 0.29 & 11.41 & 0.16 \\
\hline 135 & 30 & 0.42 & 0.79 & 13.82 & $>0.38$ & 3.28 & 0.49 & 11.18 & 0.17 \\
\hline 135 & 60 & 0.49 & 0.91 & 13.22 & $>0.43$ & 2.65 & 0.20 & 11.62 & 0.21 \\
\hline 135 & 200 & 0.49 & 1.24 & 13.39 & $>0.52$ & 2.56 & 0.16 & 11.93 & 0.38 \\
\hline 139 & 30 & 0.56 & 1.56 & 12.84 & $>0.36$ & 1.50 & 0.06 & 11.77 & 0.17 \\
\hline 139 & 70 & 0.46 & 0.97 & 12.43 & $>0.46$ & 1.62 & 0.08 & 11.66 & 0.15 \\
\hline 139 & 150 & 0.62 & 1.13 & 12.94 & $>0.42$ & 1.70 & 0.11 & 11.84 & 0.43 \\
\hline 139 & 200 & 0.47 & 0.74 & 12.78 & $>0.39$ & 1.62 & 0.04 & 12.28 & 0.40 \\
\hline 148 & 20 & 0.96 & 1.52 & 13.05 & $>0.36$ & 3.25 & 0.36 & 11.32 & 0.16 \\
\hline 148 & 30 & 1.02 & 1.79 & 13.89 & $>0.40$ & 2.29 & 0.25 & 11.31 & 0.17 \\
\hline 148 & 40 & 0.38 & 1.20 & 12.24 & $>0.60$ & 2.67 & 0.79 & 10.83 & 0.22 \\
\hline 148 & 50 & 0.58 & 0.91 & 12.98 & $>0.38$ & 2.60 & 0.22 & 11.50 & 0.18 \\
\hline 148 & 70 & 0.76 & 0.91 & 12.74 & $>0.31$ & 1.95 & 0.08 & 11.48 & 0.09 \\
\hline 162 & 20 & 1.57 & 1.76 & 12.30 & 1.28 & 2.19 & 0.24 & 11.40 & 0.25 \\
\hline 162 & 30 & 1.27 & 1.98 & 12.60 & $>0.38$ & 0.76 & 0.04 & 11.96 & 0.60 \\
\hline 162 & 40 & 0.66 & 0.93 & 12.30 & $>0.35$ & 0.97 & 0.41 & 11.69 & $>0.68$ \\
\hline 162 & 50 & 0.49 & 0.29 & 13.71 & 0.25 & 2.11 & 0.24 & 11.55 & 0.47 \\
\hline 162 & 70 & 0.87 & 1.56 & 12.44 & $>0.43$ & 1.11 & 0.11 & 11.87 & 0.71 \\
\hline 162 & 70 & 0.35 & 0.45 & 13.21 & 1.68 & 1.46 & 0.18 & 11.46 & 0.32 \\
\hline 162 & 100 & 0.68 & 0.85 & 12.42 & $>0.33$ & 2.30 & 0.38 & 11.27 & 0.30 \\
\hline 162 & 150 & 0.34 & 0.31 & 12.66 & 0.67 & 1.63 & 0.29 & 11.28 & 0.37 \\
\hline 162 & 200 & 0.63 & 0.81 & 12.39 & $>0.33$ & 1.44 & 0.08 & 11.65 & 0.15 \\
\hline 170 & 20 & 0.58 & 0.84 & 12.75 & $>0.35$ & 1.59 & 0.13 & 11.55 & 0.23 \\
\hline 170 & 40 & 0.37 & 0.12 & 12.73 & 0.14 & 1.67 & 0.10 & 11.53 & 0.15 \\
\hline 196 & 50 & 1.67 & 1.35 & 12.73 & 0.48 & 0.75 & 0.87 & 10.89 & $>0.43$ \\
\hline 204 & 60 & 0.71 & 0.66 & 12.95 & 0.66 & 2.83 & 0.40 & 11.41 & 0.25 \\
\hline 204 & 80 & 1.13 & 2.62 & 13.50 & $>0.46$ & 2.20 & 0.21 & 11.89 & 0.41 \\
\hline \multicolumn{10}{|c|}{ OUT stations } \\
\hline 160 & 30 & 0.94 & 0.68 & 12.64 & 0.43 & 1.25 & 0.51 & 11.33 & $>0.36$ \\
\hline 160 & 50 & 0.87 & 0.76 & 13.44 & 0.48 & 1.21 & 0.29 & 11.39 & 0.98 \\
\hline 160 & 70 & 0.96 & 0.37 & 13.87 & 0.16 & 3.10 & 0.18 & 11.56 & 0.12 \\
\hline 199 & 30 & 0.84 & 0.79 & 12.34 & 0.73 & 1.51 & 0.08 & 11.92 & 0.33 \\
\hline 199 & 50 & 0.72 & 0.41 & 12.60 & 0.28 & 0.83 & 0.12 & 11.55 & 0.41 \\
\hline 199 & 100 & 1.23 & 1.36 & 13.16 & $>0.30$ & 1.13 & 0.38 & 12.04 & $>0.81$ \\
\hline 199 & 150 & 0.33 & 0.15 & 12.96 & 0.19 & 1.85 & 0.51 & 11.25 & 0.57 \\
\hline
\end{tabular}

has been previously performed and the results can be found elsewhere (Laglera et al., 2011; van den Berg, 2006). The objectives were: i) determine whether the contribution to iron complexation of both model ligands could be determined and ii) if that was the case, to ascribe the added ligand to a specific ligand class $\left(\mathrm{L}_{1}\right.$ or $\left.\mathrm{L}_{2}\right)$.

It should be mentioned that there is another CLE-AdCSV protocol based in the formation of electrolabile complexes of iron with TAC (2(2-thiazolylazo)-p-cresol) that shows the same analytical limitation to resolve iron complexation by HS (Laglera et al., 2011). This has been confirmed in recent experiments combining iron titrations in the presence of the competing ligands SA (salycilaldoxime) and TAC with HS measurements (data not published). Therefore, since all previous studies about ligand release during OIF experiments (Boye et al., 2005; Kondo et al., 2008) used TAC as competing ligand, those were also limited to non-humic ligands, facilitating the comparison with the results presented in this work.

In order to ascertain the interference from HS before the start of the experiment, we determined the concentration of HS in three samples (from $20 \mathrm{~m}$ deep, days -1 and 13 and $60 \mathrm{~m}$ deep from day 0 ) following an established procedure (Laglera et al., 2007) with internal calibration using the same SRFA standard.

\section{Results}

\subsection{Dissolved iron during LOHAFEX}

Even though the temporal evolution of DFe during LOHAFEX was addressed in a previous publication (Laglera et al., 2017), the present study of iron organic speciation requires that we briefly revisit DFe concentrations for those samples where organic complexation was determined. Vertical profiles of DFe and ligand concentrations are shown in Fig. 2 and the temporal evolution of DFe in the fertilized patch down to $200 \mathrm{~m}$ in Fig. 3A.

Briefly, during the growth stage, DFe concentrations down to $200 \mathrm{~m}$ were barely increased by the initial fertilization (from $\sim 0.2$ to $\sim 0.3 \mathrm{nM}$ despite an addition equivalent to $2.4 \mathrm{nM}$ throughout the ML). This is due to the rapid formation of inorganic colloids wider than our $0.2 \mu \mathrm{m}$ filters (Laglera et al., 2017). During the grazing stage (days 14 to 34), $\mathrm{DFe}$ concentrations increased moderately down to $200 \mathrm{~m}$ but substantially in the upper $40 \mathrm{~m}$ of the water column to the range $0.5-0.7 \mathrm{nM}$ with values up to $1.3 \mathrm{nM}$. This increase was observed before the second fertilization and it was mostly caused by the release of DFe from cells and copepod fecal pellets via sloppy feeding due to the increment of the copepod grazing pressure. During the dilution stage (day 25 onwards), DFe profiles were not affected by the second fertilization and became incoherent with scattered concentrations up to $0.9 \mathrm{nM}$ down to $100 \mathrm{~m}$ deep. The same scattering of DFe concentrations was 


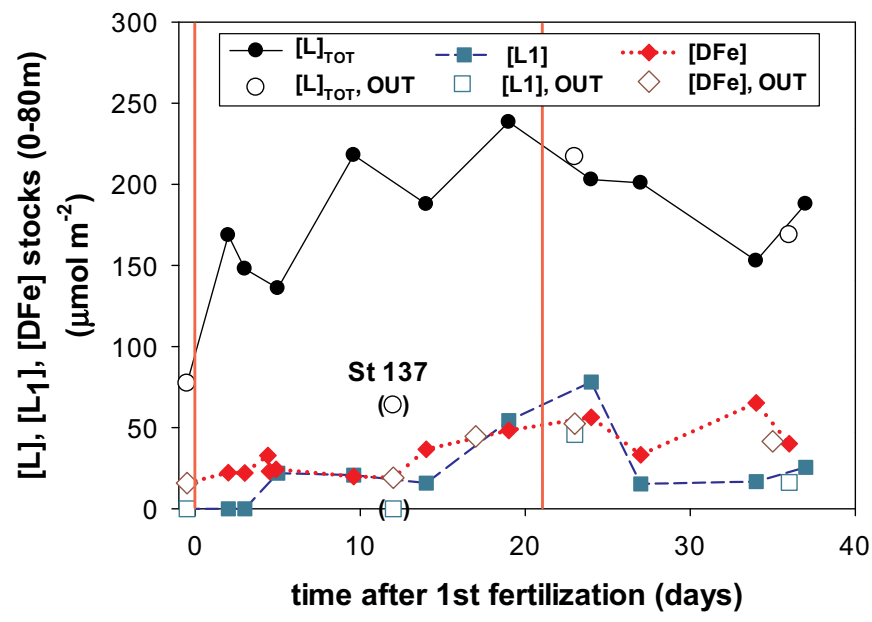

Fig. 4. Temporal evolution during LOHAFEX of the standing stocks of DFe, ligands assuming a one ligand model, and $\mathrm{L}_{1}$ ligands assuming a two types of ligands model over the upper $80 \mathrm{~m}$ of the water column. Values found in nonfertilized waters are shown with open symbols. The red vertical lines indicate the two fertilization events. Station 137 has been highlighted to indicate that although it was planned in fertilized waters, samples were representative of non-fertilized waters. (For interpretation of the references to colour in this figure legend, the reader is referred to the web version of this article.)

found at stations sampled in non-fertilized waters during the second half of the experiment. DFe scattering was mainly the result of the continuous remineralization of iron-enriched copepod fecal pellets together with the decrease of iron requirements by the biological community (NCP went down to $\sim 0$ after day 23) (Laglera et al., 2017).

\subsection{Addition of model ligands to LOHAFEX samples}

Since the ubiquitous presence of HS in seawater is widely acknowledged (Batchelli et al., 2010; Laglera and van den Berg, 2009; Tani et al., 2003), we carried out specific tests (summarized in Fig. S3 and Table S1) by adding fulvic acid (SRFA) and desferroxamine B to LOHAFEX samples in order to define their contribution to our results.

On one hand, we corroborated previous reports about the inability of the $\mathrm{DHN} / \mathrm{BrO}_{3}{ }^{-}$method to estimate the contribution of $\mathrm{HS}$ to iron complexation. Iron titration of samples spiked with a concentration of SRFA equivalent to an iron complexing capacity of $2.0 \mathrm{nM}$ did not show a significant increase of complexing capacities. Therefore, all ligand concentrations reported in this work do not include the contribution of HS. On the other hand, we corroborated that the $\mathrm{DHN} / \mathrm{BrO}_{3}{ }^{-}$protocol (Laglera et al., 2011; van den Berg, 2006) is valid to obtain accurate estimations of the concentrations of ligands such as siderophores: an increment of the complexing capacity of $2.1 \pm 0.1 \mathrm{nM}$ was detected for an addition of $2 \mathrm{nM}$ DFB.

Interestingly, after the addition of a concentration of DFB that doubled the original ligand concentration (from 1.8 to $3.9 \mathrm{nM}$ ), the Scatchard plot of the iron titration remained linear (Fig. S4A) and log $\mathrm{K}_{\mathrm{Fe}}^{\prime} \mathrm{L}$ did not change significantly $(11.67 \pm 0.15$ and $11.80 \pm 0.10$ before and after DFB addition). This $\log \mathrm{K}_{\mathrm{Fe}_{\mathrm{L}} \mathrm{L}}^{\prime}$ implies that the conditional stability constant of the Fe-DFB complex is not significantly higher than that of the pool of ligands initially present in sampled waters. In order to stress the difference in between DFB and $\mathrm{L}_{1}$, we show in Fig. S4B a Scatchard plot of a selected LOHAFEX sample where two types of ligands could be determined. In our experimental conditions, DFB belonged to the $\mathrm{L}_{2}$ class and not to the $\mathrm{L}_{1}$ ligands detected after day 5 of the experiment (see below).

The percentage of labile iron with respect to DFe found after overnight equilibration with $0.5 \mu \mathrm{M}$ DHN in LOHAEFX samples averaged at $34 \pm 26 \%$.

\subsection{Iron speciation during LOHAFEX. single ligand model}

Ligand concentrations and conditional stability constants were first calculated assuming the existence of one single type of ligand (values in Table 2 and profiles in Fig. 2). We found ligand concentrations considerably in excess of DFe concentrations in all samples but two: the $20 \mathrm{~m}$ deep sample collected before the initial fertilization where ligands were below the limit of detection and the $20 \mathrm{~m}$ depth sample at station $137([\mathrm{~L}]=74 \%$ of $[\mathrm{DFe}]$ ). Ligand concentrations smaller than $\mathrm{DFe}$ concentrations are found rarely in oceanographic studies although it was the case at one surface sample in a previous study of iron complexation in waters of the Southern Ocean (Boye et al., 2001). Sample collection at Station 137 (day 13) was planned for fertilized waters but the Chl-a standing stock (Fig. S1), our iron partitioning data (Laglera et al., 2017) and iron speciation data (this work) indicate that at the time we performed the "trace metals" hydrocast, the ship had drifted out of the fertilized patch. We present a detailed case about labelling station 137 as an OUT station in Section 1.1 of the supplementary information file. For the rest of the samples, [L] varied in the range 0.6 to $3.9 \mathrm{nM}$ (average $2.2 \pm 0.7, n=72$ ) with $[\mathrm{L}] / \mathrm{DFe}$ ratios in the range 1.4 to 19.1 (average $6.4 \pm 3.4$ ). Ligand conditional stability constants averaged at $\left.\log \mathrm{K}_{\mathrm{Fe}^{\prime} \mathrm{L}}^{\prime}=11.89 \pm 0.30, n=63\right)$. The $\log \mathrm{K}_{\mathrm{Fe}^{\prime} \mathrm{L}}^{\prime}$ did not show any significant temporal or vertical trend and values were similar to those found at OUT stations $\left(\log \mathrm{K}_{\mathrm{Fe} \mathrm{L}}^{\prime}=11.88 \pm 0.35, n=22\right)$ (Fig. S5).

The temporal evolution of ligand concentrations as a function of depth in fertilized waters during LOHAFEX is presented in Fig. 3B. Prior to the initial fertilization, the vertical ligand profile ( 30 to $300 \mathrm{~m}$ ) was featureless with an average ligand concentration of $1.5 \pm 0.3 \mathrm{nM}$. The increase of ligand concentrations during the growth stage was mostly confined to MLD waters where ligand concentrations nearly doubled (to $\sim 2.5 \mathrm{nM}$ ). High ligand concentrations of $2 \mathrm{nM}$ or above were found in $100 \mathrm{~m}$ deep samples at the first three stations (days $-1,2$ and 3). We do not have enough evidence to classify those data points as outliers nor to claim the existence of a thin layer at $100 \mathrm{~m}$ depth with high ligand concentrations due to recycling processes detailed below in Section 4.3.

Through the grazing stage, ligand concentrations i) further increased in the upper $70 \mathrm{~m}$ reaching values of $>3 \mathrm{nM}$, ii) increased moderately $(\sim 2 \mathrm{nM}$ ) below the MLD down to $200 \mathrm{~m}$, and iii) scattered high values gave inconsistent $[\mathrm{L}]$ profiles.

During the dilution stage the depth evolution of ligand concentrations was opposite to the distribution found during the grazing stage: i) in the upper $50 \mathrm{~m}$ there was a substantial reduction of ligand concentrations $(<2 \mathrm{nM})$ and ii) below $50 \mathrm{~m}$ there were higher ligand concentrations $(>2 \mathrm{nM}$ ) with a significant accumulation in the 60-100 $\mathrm{m}$ depth interval.

A plot of ligand standing stocks in the upper $80 \mathrm{~m}$ (Fig. 4) confirms the referred increment of ligand concentrations during the growth stage with a ligand standing stock increment from 77 to $\sim 200 \mu \mathrm{mol} \mathrm{L} \mathrm{m}{ }^{-2}$. During the grazing stage, the ligand standing stock in the fertilized waters was stable at $\sim 230 \mu \mathrm{M}$ ligand $\mathrm{m}^{-2}$ (equivalent to $\sim 3.0 \mathrm{nM}$ if averaged over $80 \mathrm{~m}$ deep). During the dilution stage, ligand standing stocks decreased slightly to $\sim 190 \mu \mathrm{mol} \mathrm{L} \mathrm{m}^{-2}$ (equivalent to concentrations in the range 2.0 to $2.5 \mathrm{nM}$ ) despite the dilution and fragmentation experienced by the fertilized patch. This is partially explained by a lack of horizontal dilution during the last two stages of the experiment. After day 23, ligand concentrations found at OUT stations were similar to those determined in the fertilized waters.

\subsection{Iron speciation during LOHAFEX. two ligands model}

In many samples collected after day 5, we could apply a two ligands model and quantify the presence of a new type of ligand characterized by significantly higher $\log \mathrm{K}_{\mathrm{Fe}}^{\prime} \mathrm{L}$ than those originally present. Those samples in which we were able to resolve 2 types of ligands are marked in Fig. 3B with red crosses, and the complexing parameters are given in 
Table 3. The newly detected group of ligands was found at concentra-

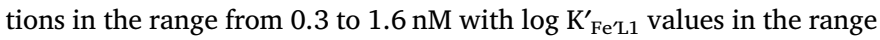
from 12.2 to 13.4. Those concentrations account for a significant percentage of the increment of total ligand concentrations reported above (Fig. 4). During the growth stage, $\mathrm{L}_{1}$ was detected preferentially in the upper $80 \mathrm{~m}$ (Fig. 3B). Through the grazing stage, $\mathrm{L}_{1}$ was detected in nearly all samples above $80 \mathrm{~m}$ but also in many samples from deeper layers. During the dilution stage, $\mathrm{L}_{1}$ was below detection limits in the upper $50 \mathrm{~m}$ but it was found in many samples from deeper layers. Therefore, the temporal and spatial distribution of samples with $\mathrm{L}_{1}$ ligands is approximately coincident with the patterns described above for the temporal and spatial variability of the complexing capacity according to a single ligand model (Fig. 3B). Ligand conditional stability constants of $\mathrm{L}_{2}$ ligands averaged at $\log \mathrm{K}_{\mathrm{Fe} \text { 'L2 }}^{\prime}=11.59 \pm 0.30$, $n=38$ ). This is only 0.3 logarithmic units below the $\log \mathrm{K}_{\mathrm{Fe}^{\prime} \mathrm{L}}^{\prime}$ for a single ligand model, confirming that L ligands were predominantly $\mathrm{L}_{2}$ ligands.

It should also be noted that, in some samples from OUT stations collected after the second fertilization (stations 160 and 199 corresponding to days 23 and 36, respectively), it was possible to find a solution for a two types of ligand model in line with the results found inside the patch (Table S2). This is not surprising since the same processes that controlled biomass distribution in the fertilized waters were also predominant in the unfertilized waters of the selected eddy (Martin et al., 2013) (see below for a more detailed description of those processes).

\section{Discussion}

\subsection{Iron speciation prior to fertilization}

Before the initial fertilization, DFe concentrations in the MLD were low (at $\sim 0.2 \mathrm{nM}$ ) but not depleted (DFe $\leq 0.1 \mathrm{nM}$ ) as it is characteristic of HNLC areas (Chever et al., 2010; Nishioka and Obata, 2017). A recent study has suggested that biotic iron requirements are not so different in ocean locations characterized by very different DFe concentrations, and were reported at $\sim 0.10 \pm 0.03 \mathrm{nM}$ (Boyd et al., 2015). Nevertheless, extra biomass growth as a response to iron additions has been found in incubations of Southern Ocean waters with DFe concentrations as high as $5 \mathrm{nM}$ (Buck et al., 2010). Only a severe restriction of the bioavailability of iron species can be compatible with this scenario. It is common understanding that iron bioavailability is restricted by the presence of either strong ligands (Hutchins et al., 1999) or inert (aged) colloids (Rich and Morel, 1990). However, the LOHAFEX phytoplankton community was dominated by flagellates, well known for their ability to take up colloidal iron by phagotrophy (Nodwell and Price, 2001). Moreover, strong ligands, as those forming the $\mathrm{L}_{1}$ class, were not detected before day 5 of the experiment. We cannot say whether the restricted bioavailability of iron was related to the apparent presence of Fe-HS complexes since previous reports on their bioavailability are contradictory. It has been reported that the addition of HS to incubations accelerates (Chen and Wang, 2008) or reduces (Fujii et al., 2013) iron assimilation. Unfortunately, we do not have enough information to put forward a comprehensive hypothesis about the limited bioavailability of the initial iron standing stock.

The initial ligand standing stock in the upper $80 \mathrm{~m}$ was $77 \mu \mathrm{mol} \mathrm{m}^{-2}$, significantly higher than the initial DFe standing stock of $17 \mu \mathrm{mol} \mathrm{Fe} \mathrm{m}^{-2}$, but insufficient to complex an increment of $120 \mu \mathrm{mol}$ Fe $\mathrm{m}^{-2}$ throughout the patch.

\subsection{The relationship of iron speciation and iron partitioning}

Nearly all the iron added during both fertilizations was rapidly removed (<3 days) from the dissolved fraction (Laglera et al., 2017). Here we want to evaluate if organic speciation played a role in this process.
Although a fraction of DFe added in the first fertilization was taken up by autotrophs (necessary to explain the increase of the $\mathrm{Fv} / \mathrm{Fm}$ ratio), the excess inorganic iron must have formed oxyhydroxides that would grow until reaching such a size that prevented their collection in the dissolved fraction $(<0.2 \mu \mathrm{m})$. In previous fertilizations, this process was completed in 3 days. Inorganic particles would continue growing and aggregating to other particulate phases until reaching a volume that would lead to their slow scavenging below the MLD. Slow sinking of inorganic particulate iron is supported by the finding on days 14 and 18 of an accumulation of abiotic particulate iron at 50-100 m depth (Laglera et al., 2017).

As a result of the increasing grazing pressure DFe standing stocks had approximately doubled on day 14 to $\sim 50 \mu \mathrm{mol} \mathrm{Fe} \mathrm{m}^{-2}$. By the time of the second fertilization on day 21 , ligand standing stocks were found at $\sim 200 \mu \mathrm{mol}$ ligand $\mathrm{m}^{-2}$. In those conditions, an addition of $120 \mu \mathrm{mol}$ Fe $\mathrm{m}^{-2}$ throughout the patch probably was fully complexed, reducing (probably not cancelling) substantially the formation of oxyhydroxides. This explains the completely different pattern followed by iron partitioning after the second fertilization (Laglera et al., 2017). Interestingly, 3 days after the second fertilization DFe standing stocks had not changed significantly. Abiotic mineral phases had decreased significantly by day 21 and contrary to our observations after the first fertilization, two weeks after the second fertilization there was no obvious accumulation of abiotic particulate iron at 50-100 m depth. The fraction stored in copepod fecal pellets increased significantly after the second fertilization becoming the main contributor to iron partitioning. The increment of the iron per copepod fecal pellet concentration can only be explained if a significant fraction of iron from the second fertilization was rapidly taken up by phytoplankton, then grazed by copepods and released as iron-rich fecal pellets. The low POC export, when compared to NCP (Martin et al., 2013), indicates that pellet recycling was fast and necessarily contributed significantly to the release of DFe and iron ligands from particles. However, DFe release did not lead to its accumulation. This can be explained from the high requirement for iron of the autotrophic community during the grazing stage since its biomass had increased significantly and at the moment of the second fertilization NCP was at its maximum (Martin et al., 2013). DFe was probably released as $\mathrm{FeL}_{1}$ complexes because $\mathrm{L}_{1}$ would outcompete weaker ligands. The absence of DFe accumulation in the MLD indicates that the release of significant concentrations of $\mathrm{L}_{1}$ did not interfere with DFe bioavailability. Iron bioavailability is mostly linked to the reduction of complexed $\mathrm{Fe}(\mathrm{III})$ to the more bioavailable species $\mathrm{Fe}(\mathrm{II})$ (Morrissey and Bowler, 2012). We will provide a possible explanation to the high bioavailability of Fe- $\mathrm{L}_{1}$ complexes in the next section.

\subsection{The effect of major biochemical processes in modulating iron ligand release}

Iron organic speciation in surface ocean waters is modulated by many biochemical processes that constitute sources and sinks of ligands. A non-comprehensive list includes: uptake of metal-ligand complexes by phyto- and bacterioplankton, exudation of ligands by phyto- and bacterioplankton, photodegradation, bacterial remineralization of POC, scavenging after adsorption to sinking particles or as part of aggregates, liberation from grazing by zooplankton during ingestion (sloppy feeding) and excretion, cell lysis (either by natural causes or after viral infection), etc. (Gledhill and Buck, 2012; Sato et al., 2007).

Our experimental setting did not allow estimating the relative importance of the cited processes during LOHAFEX. Nonetheless, data interpretation in our case is facilitated by some conditions verified during our experiment (Martin et al., 2013; Mazzocchi et al., 2009; Thiele et al., 2014). First, the composition of the phytoplanktonic and bacterioplankton communities showed a remarkable stability throughout the experiment without differences between fertilized and non-fertilized waters (Schulz et al., 2018; Thiele et al., 2012); the surge 
of $\mathrm{L}_{1}$ was not proceeding from a shift of the biological community. Second, some variables showed time changes at IN stations that were mimicked by changes at OUT stations. The list of variables includes DFe (Laglera et al., 2017), ligand concentrations and the presence of $\mathrm{L}_{1}$ (this work); horizontal dilution was not a relevant factor in order to explain changes in the temporal evolution of the distribution of ligands. Third, grazing by large copepods, exerted during the grazing and dilution stages of LOHAFEX, provided a top-down control of the patch biomass and iron partitioning in fertilized and non-fertilized waters, contributing to the efficient recycling of POC and iron in the upper $100 \mathrm{~m}$ (Laglera et al., 2017; Martin et al., 2013). Since copepod grazing is characterized by sloppy feeding of as much as $50 \%$ of the carbon content of food (Møller et al., 2003) and coprophagy of their own fecal pellets (Iversen and Poulsen, 2007), ligand exudation and bacterial remineralization cannot be considered here the main sources of ligands during LOHAFEX. The above mentioned processes simplify the interpretation of the temporal evolution of ligands during LOHAFEX.

During the initial growth stage (up to day 12), the 2.5-fold accumulation of iron ligands was concomitant with a 2.2 -fold increase of the Chl-a standing stock both restricted to the MLD (60-80 m) (Figs. 1B, S1, $3 \mathrm{~B}$ and 4 ). By the time $\mathrm{L}_{1}$ ligands were measurable (day 5) the ligand standing stock in the upper $80 \mathrm{~m}$ had already doubled. In previous OIFs, the initial major accumulation of ligands was assigned to phytoplankton exudation (Boye et al., 2005; Rue and Bruland, 1997; Wells, 2003). During the first 10 days there were no significant changes in DFe concentrations and the grazing pressure of copepods was increased until reaching the control over the planktonic biomass (Martin et al., 2013; Mazzocchi et al., 2009). However, the increase of the ligand stock started much earlier (many hours) than the period required to build a zooplankton response to any phytoplankton bloom (few days) (Atkinson, 1998). We hypothesize that during the growth stage the main process changing iron organic speciation was the accumulation of planktonic exudates.

During the grazing stage (days 10 to 25), ligand concentrations in the upper $80 \mathrm{~m}$ of the fertilized waters reached a stable maximum (Fig. 4). From day 10 onwards there was an increase of ligand concentrations below the MLD down to $200 \mathrm{~m}$ depth. Since viable phytoplankton could only be found in the upper $80 \mathrm{~m}$ of the water column, fresh ligands found below could not be the result of exudation. This vertical distribution of ligands was concomitant with changes in the distribution of DFe (Laglera et al., 2017) and the vertical migration down to $200 \mathrm{~m}$ of the copepod C. simillimus during LOHAFEX (Mazzocchi et al., 2009). $\mathrm{L}_{1}$ was also present in many samples above and below the MLD. $\mathrm{L}_{1}$ standing stocks in the upper $80 \mathrm{~m}$ (30 to $50 \mu \mathrm{mol} \mathrm{L} \mathrm{L}^{-2}$ ) amounted to about $1 / 3$ of the increase of the overall ligand stock. The other $2 / 3$ were weaker $\mathrm{L}_{2}$ ligands that approximately doubled their concentration. We hypothesize that during the grazing stage, sloppy feeding during copepod grazing of cells and pellets was the major process of release of DFe and ligands mostly in the form of strong $\mathrm{FeL}_{1}$ complexes.

Validation of this hypothesis requires a strong relation between $L_{1}$ and DFe concentrations (Fig. S6). While overall ligands and DFe concentrations are poorly correlated (Pearson correlation: $r=0.297$; $P=0.011 ; n=72)$, DFe and $\mathrm{L}_{1}$ concentrations showed an excellent positive correlation $(r=0.824 ; P<0.001 ; n=31)$ (Fig. S6). The slope of the least squares linear regression close to 1 at $1.08 \pm 0.14 \mathrm{nML}_{1}$ $(\mathrm{nM} \mathrm{DFe})^{-1}$ suggests that DFe was associated quantitatively with $\mathrm{L}_{1}$. The presence of $L_{1}$ concentrations in samples from OUT stations 160 and 199 (Table 3) can be explained from the fact that the grazing pressure by large copepods did not show differences between fertilized and non-fertilized waters during the second part of the experiment (Mazzocchi et al., 2009). The broad distribution of $\mathrm{L}_{1}$ supports the hypothesis that similar temporal and vertical DFe distributions at IN and OUT stations were caused by grazing processes (Laglera et al., 2017). Prior incubation experiments with copepods grazing in local plankton assemblages have shown liberation of iron complexes with strong ligands (Boyd et al., 2012; Sato et al., 2007).

During the dilution stage the small decrease of the ligand stock in the upper $80 \mathrm{~m}$ with respect to the grazing stage $(\sim 15-20 \%)$ was mostly due to the vanishing of $\mathrm{L}_{1}$ from the upper $50 \mathrm{~m}$ of the water column. DFe of those samples did not show any significant variation (Fig. 3A) implying the existence of a biochemical process that removed selectively $\mathrm{L}_{1}$ from surface waters and became dominant in surface waters during the $d i$ lution stage. Ligands other than $\mathrm{L}_{1}$ must have a stronger resilience to degradation processes. Below $50 \mathrm{~m}, \mathrm{~L}_{1}$ continued to be present in some samples and ligand accumulation continued across the MLD. During the dilution stage, there was a reduction of the grazing pressure and $\mathrm{DFe}$ requirements by phytoplankton (manifested by nearly constant Chl-a concentrations and a reduction of NCP to zero) diminishing the role of sloppy feeding and fecal pellet recycling as ligand sources. Since shortlived $\mathrm{L}_{1}$ disappeared exclusively from the upper $50 \mathrm{~m}$ and not from the depth of penetration of Chl-a (about $80 \mathrm{~m}$ ), iron uptake of dissolved $\mathrm{FeL}_{1}$ complexes by phytoplankton was probably not the main $\mathrm{L}_{1}$ sink. The most plausible reason was photodegradation by solar radiation (Powell and Wilson-Finelli, 2003). In a recent work, the short residence times of ligands found in surface waters at the ALOHA station were similarly ascribed to photodegradation (Fitzsimmons et al., 2015).

\subsection{What was the nature of $L_{1}$ ?}

Despite recent advances in separation and characterization techniques, the main unresolved problem in the study of iron speciation in natural waters is the identification of those ligands existing in natural waters. Currently, we only have a reduced (and probably not definitive) list of candidate compounds (siderophores, pigment-like compounds including the heme group, humic substances and polysaccharides) but there is no consensus in the scientific community about their relative importance. Many authors have favored the hypothesis that the strong ligands often found in natural seawater are siderophores exudated by prokaryotes (Gledhill and Buck, 2012; Hunter and Boyd, 2007).

Here, via the repetition of the CLE-AdCSV analysis of a natural sample after the addition of a specific ligand to a natural sample we prove that the siderophore DFB belongs to the pool of weaker ligands dominant during the initial stages of the experiment $\left(\mathrm{L}_{2}\right)$. However, since the range of thermodynamic (not conditional) stability constant of siderophores extends over $>20$ orders of magnitude $\left(\log \beta_{\mathrm{FeL}}=16-39\right)$ (Dhungana and Crumbliss, 2005), we cannot rule out that $\mathrm{L}_{1}$ included siderophores with stronger affinity for iron than DFB. Cathecolate siderophores such as alterobactin A and B and enterobactin have shown conditional stability constants several orders of magnitude higher than hydroxamate siderophores such as DFB when analyzed on competition against 1-nitroso-2-naphtol (Witter et al., 2000).

Siderophore exudation by cyanobacteria would be mostly restricted to surface waters with a minor or negligible presence below the MLD (Boyd and Ellwood, 2010; Boyd and Tagliabue, 2015; Hassler et al., 2017). However, during LOHAFEX, $\mathrm{L}_{1}$ was found at depths well below the MLD. Several groups have pursued to detect siderophores in ocean waters but only recently there has been success in their quantification by using chromatographic techniques coupled to mass spectrometry. The combined concentration of different siderophores in the water column was always found at the low picomolar, just a minimum percentage of DFe concentrations or the ligand concentrations found by CLE-AdCSV (Boiteau et al., 2016; Mawji et al., 2008). All variables related to the action of autotrophs, Chl-a stock, primary production and net community production, were clearly higher in fertilized waters. If the exudation by phytoplankton had been the main source of ligands, there would probably be a remarkable difference between IN and OUT stations. Moreover, since previous incubation experiments have shown that siderophore exudation is inversely correlated to DFe concentrations (Wilhelm and Trick, 1994), an accumulation of siderophores is unlikely in our conditions of increasing and non-limiting DFe concentrations (Fig. 3A). 
We have shown above that $\mathrm{L}_{1}$ release was linked to DFe, whose vertical distribution became controlled by the fate of copepod fecal pellets as the experiment progressed (Laglera et al., 2017). The type of ligands that could be released in the medium via cell lysis during sloppy grazing and recycling of fecal pellets (packed with phytoplanktonic cells) are intracellular ligands such as hemes (pigments containing the iron binding moieity porphyrin). In cultures of marine phytoplankton, protoporphyrin (IX) complexed around a fifth of the total cellular iron (Honey et al., 2013). Flagellates, the major component of phytoplankton during LOHAFEX, also produce porphyrin compounds (such as phaeophytin, Chl-a without the $\mathrm{Mg}^{2+}$ ion), which are strong iron ligands, that are released by zooplankton grazing (Strom, 1993; Strom et al., 1998). Previous work in UV-digested seawater found that $\log \mathrm{K}^{\prime}{ }_{\mathrm{Fe}}^{\prime} \mathrm{L}$ of different siderophores would extend over a wide range (11.6 to $>14.0$ ) while the porphyrins protoporphyrin IX and phaeophytin showed intermediate values (log $\mathrm{K}_{\mathrm{Fe}^{\prime} \mathrm{L}}=12.2$ and 12.4 , respectively) (Witter et al., 2000). Although we have to take comparisons with extreme caution, the referred $\log \mathrm{K}_{\mathrm{Fe}}^{\prime}$ porphyrins is about $0.7 \log$ units higher than $\log \mathrm{K}_{\mathrm{Fe} \text { DFB }}^{\prime}$ using the same analytical method (Witter et al., 2000), 0.8 units higher than $\log \mathrm{K}_{\mathrm{Fe}^{\prime} \mathrm{L}}^{\prime}$ found in this work for overall ligands (11.9 $\pm 0.3, n=63)$ and about 0.6 units below the $\log \mathrm{K}_{\mathrm{Fe} \text { L1 }}^{\prime}$ found in this work $(12.9 \pm 0.5, n=38)$. Therefore, it is reasonable to hypothesize that intracellular phytoplankton ligands could constitute a separate ligand class. Recent advances in chromatographic and chemiluminescence techniques have allowed the quantification of heme compounds in seawater (Gledhill et al., 2013; Vong et al., 2007) but again those concentrations found in ocean waters are in the low picomolar range which would account for only a minor fraction of the iron complexing capacity measured by CLE-AdCSV (Gledhill et al., 2013; Hogle et al., 2014). However, in the case of porphyrins in solution in the presence of oxygen, photodegradation occurs at wavelengths as high as $600-700 \mathrm{~nm}$ (Ericson et al., 2003) which would explain their disappearance in surface waters during the dilution stage once the grazing pressure was reduced. Catecholate siderophores are more susceptible to photolysis once deferrated (Barbeau et al., 2003) which would be unlikely in ocean waters since they show the higher affinity for iron. Hydroxamate siderophores can be photoxidized but the products are iron ligands of lower affinity (Barbeau et al., 2001). In previous studies in waters of the Southern Ocean, the high photoreactivity of in situ ligands was in strong contrast with the lack of photolability of several siderophores (Maldonado et al., 2005). Moreover, ligands as pigments that absorb solar radiation (leading or not to photobleaching) are prone to photogenerate and bind the bioavailable species Fe(II) or superoxide, a precursor of Fe(III) reduction (Rijkenberg et al., 2006). Release of photosensitive strong ligands possibly contributed to the long life of the LOHAFEX bloom.

Despite not having direct spectroscopic proof, all evidence is consistent with the ascription of the nature of $L_{1}$ to phytoplanktonic intracellular ligands rather than to siderophores.

\subsection{Could be grazing a major source of iron ligands in ocean waters?}

LOHAFEX was carried out in the recycling, flagellate-dominated plankton community characteristic of the summer season in silicate depleted water along the Polar Front. We were lucky inasmuch as the same zooplankton community prevailed during the duration of the experiment over an area very much larger than the entire eddy, implying that the zooplankton community inside and outside the fertilized patch was essentially similar. Our observations confirm the hypothesis that biomass build-up by the microbial community is constrained by regeneration of essential nutrients and micronutrients by zooplankton (Smetacek et al., 1990). Copepod fecal pellets were an integral part of the regenerating network, and the recycling of their high iron content explains the remarkably high chlorophyll biomass that was maintained in the patch for at least 4 weeks after the second fertilization.

We observed during LOHAFEX a substantial increase of the concentration of iron ligands in surface waters below and above the ML and in fertilized and non-fertilized waters pointing to grazing as the predominant biological cause of ligand build up and changes in the organic speciation of iron. This scheme implies that during a certain period of time a significant proportion of iron and iron ligands is held in the pool constituted by fast swimming organisms (such as copepods) and their fecal products. From a practical point of view, the evaluation of trace metal cycling becomes extraordinarily difficult since copepod cannot be sampled with Go-FLo bottles and it is very difficult to get representative samples of their fecal products. Moreover, since copepods are not disturbed by the patch dilution and their main motion is a vertical daily migration they contribute to mitigate iron dilution and thus help extend the life of blooms.

The role of zooplankton grazing on iron storage and recycling (Barbeau et al., 1996; Hutchins et al., 1995; Sarthou et al., 2008) and on ligand release (Sato et al., 2007) had been invoked before based on results obtained with onboard incubations. For LOHAFEX, we have presented for the first time analytical evidence of the iron fraction stored during an oceanic bloom by fecal pellets ( $\sim$ nearly half of total iron in the MLD) (Laglera et al., 2017) and the liberation during fecal pellet recycling of iron ligands characterized by high affinity and poor photostability.

\section{Acknowledgments}

We are grateful to Captain Stefan Schwarze and the crew of the RV Polarstern. We acknowledge the contribution of Victor Smetacek for his advice during the elaboration of this manuscript. All the members of the LOHAFEX community contributed to this work via discussion during the cruise and subsequent workshops.

This work was supported by the Government of Spain (MINECO CTM2008-01864-E/ANT and CTM2014-59244-C3-3-R).

\section{Appendix A. Supplementary data}

Supplementary data to this article can be found online at https:// doi.org/10.1016/j.jmarsys.2019.02.002.

\section{References}

Assmy, P., Smetacek, V., Montresor, M., Klaas, C., Henjes, J., Strass, V.H., Arrieta, J.M., Bathmann, U., Berg, G.M., Breitbarth, E., Cisewski, B., Friedrichs, L., Fuchs, N., Herndl, G.J., Jansen, S., Krägefsky, S., Latasa, M., Peeken, I., Röttgers, R., Scharek, R., Schüller, S.E., Steigenberger, S., Webb, A., Wolf-Gladrow, D., 2013. Thick-shelled, grazer-protected diatoms decouple ocean carbon and silicon cycles in the iron-limited Antarctic Circumpolar Current. Proc. Natl. Acad. Sci. U. S. A. 110, 20633-20638.

Atkinson, A., 1998. Life cycle strategies of epipelagic copepods in the Southern Ocean. J. Mar. Syst. 15, 289-311.

Barbeau, K., Moffett, J.W., Caron, D.A., Croot, P.L., Erdner, D.L., 1996. Role of protozoan grazing in relieving iron limitation of phytoplankton. Nature 380, 61-64.

Barbeau, K., Rue, E.L., Bruland, K.W., Butler, A., 2001. Photochemical cycling of iron in the surface ocean mediated by microbial iron(III)-binding ligands. Nature 413 , 409-413.

Barbeau, K., Rue, E.L., Trick, C.G., Bruland, K.W., Butler, A., 2003. Photochemical reactivity of siderophores produced by marine heterotrophic bacteria and cyanobacteria based on characteristic Fe(III) binding groups. Limnol. Oceanogr. 48, 1069-1078.

Batchelli, S., Muller, F.L.L., Chang, K.-C., Lee, C.-L., 2010. Evidence for strong but dynamic iron-humic colloidal associations in humic-rich coastal waters. Environ. Sci. Technol. 44, 8485-8490.

Boiteau, R.M., Mende, D.R., Hawco, N.J., McIlvin, M.R., Fitzsimmons, J.N., Saito, M.A., Sedwicka, P.N., DeLong, E.F., Repeta, D.J., 2016. Siderophore-based microbial adaptations to iron scarcity across the eastern Pacific Ocean. Proc. Natl. Acad. Sci. $113,14237-14242$.

Bowie, A.R., Maldonado, M.T., Frew, R.D., Croot, P.L., Achterberg, E.P., Mantoura, R.F.C., Worsfold, P.J., Law, C.S., Boyd, P.W., 2001. The fate of added iron during a mesoscale fertilisation experiment in the Southern Ocean. Deep-Sea Res. II Top. Stud. Oceanogr. 48, 2703-2743.

Boyd, P.W., Ellwood, M.J., 2010. The biogeochemical cycle of iron in the ocean. Nat. Geosci. 3, 675-682.

Boyd, P.W., Tagliabue, A., 2015. Using the $\mathrm{L}^{*}$ concept to explore controls on the relationship between paired ligand and dissolved iron concentrations in the ocean. Mar. Chem. 173, 52-66. 
Boyd, P.W., Jickells, T., Law, C.S., Blain, S., Boyle, E.A., Buesseler, K.O., Coale, K.H., Cullen, J.J., de Baar, H.J.W., Follows, M., Harvey, M., Lancelot, C., Levasseur, M., Owens, N.P.J., Pollard, R., Rivkin, R.B., Sarmiento, J., Schoemann, V., Smetacek, V., Takeda, S., Tsuda, A., Turner, S., Watson, A.J., 2007. Mesoscale iron enrichment experiments 1993-2005: synthesis and future directions. Science 315, 612-617.

Boyd, P.W., Strzepek, R., Chiswell, S., Chang, H., DeBruyn, J.M., Ellwood, M., Keenan, S., King, A.L., Maas, E.W., Nodder, S., 2012. Microbial control of diatom bloom dynamics in the open ocean. Geophys. Res. Lett. 39.

Boyd, P.W., Strzepek, R.F., Ellwood, M.J., Hutchins, D.A., Nodder, S.D., Twining, B.S. Wilhelm, S.W., 2015. Why are biotic iron pools uniform across high- and low-iron pelagic ecosystems? Global Biogeochem. Cycles 9, 1028-1043. https://doi.org/10. 1002/2014GB005014.

Boye, M., van den Berg, C.M.G., de Jong, J.T.M., Leach, H., Croot, P., de Baar, H.J.W. 2001. Organic complexation of iron in the Southern Ocean. Deep-Sea Res. I Oceanogr. Res. Pap. 48, 1477-1497.

Boye, M., Nishioka, J., Croot, P.L., Laan, P., Timmermans, K.R., de Baar, H.J.W., 2005 Major deviations of iron complexation during 22 days of a mesoscale iron enrichment in the open Southern Ocean. Mar. Chem. 96, 257-271.

Buck, K.N., Selph, K.E., Barbeau, K.A., 2010. Iron-binding ligand production and copper speciation in an incubation experiment of Antarctic Peninsula shelf waters from the Bransfield Strait. Southern Ocean. Mar. Chem. 122, 148-159.

Chen, M., Wang, W.-X., 2008. Accelerated uptake by phytoplankton of iron bound to humic acids. Aquat. Biol. 3, 155-166.

Chever, F., Bucciarelli, E., Sarthou, G., Speich, S., Arhan, M., Penven, P., Tagliabue, A. 2010. Physical speciation of iron in the Atlantic sector of the Southern Ocean along a transect from the subtropical domain to the Weddell Sea Gyre. J. Geophys. Res. C: Oceans 115.

Croot, P.L., Andersson, K., Ozturk, M., Turner, D.R., 2004. The distribution and specification of iron along 6 degrees E in the Southern Ocean. Deep-Sea Res. II Top. Stud. Oceanogr. 51, 2857-2879.

de Baar, H.J.W., Boyd, P.W., Coale, K.H., Landry, M.R., Tsuda, A., Assmy, P., Bakker, D.C.E., Bozec, Y., Barber, R.T., Brzezinski, M.A., Buesseler, K.O., Boyé, M., Croot, P.L., Gervais, F., Gorbunov, M.Y., Harrison, P.J., Hiscock, W.T., Laan, P., Lancelot, C., Law, C.S., Levasseur, M., Marchetti, A., Millero, F.J., Nishioka, J., Nojiri, Y., van Oijen, T., Riebesell, U., Rijkenberg, M.J.A., Saito, H., Takeda, S., Timmermans, K.R., Veldhuis, M.J.W., Waite, A.M., Wong, C.S., 2005. Synthesis of iron fertilization experiments: from the iron age in the age of enlightenment. J. Geophys. Res. C: Oceans $110,1-24$.

Dhungana, S., Crumbliss, A.L., 2005. Coordination chemistry and redox processes in siderophore-mediated iron transport. Geomicrobiol J. 22, 87-98.

Ebersbach, F., Assmy, P., Martin, P., Schulz, I., Wolzenburg, S., Nöthig, E.-M., 2014 Particle flux characterisation and sedimentation patterns of protistan plankton during the iron fertilisation experiment LOHAFEX in the Southern Ocean. Deep-Sea Res. I Oceanogr. Res. Pap. 89, 94-103.

Ericson, M.B., Grapengiesser, S., Gudmundson, F., Wennberg, A.-M., Larkö, O., Moan, J., Rosén, A., 2003. A spectroscopic study of the photobleaching of protoporphyrin IX in solution. Lasers Med. Sci. 18, 56-62.

Fitzsimmons, J.N., Hayes, C.T., Al-Subiai, S.N., Zhang, R., Morton, P.L., Weisend, R.E. Ascani, F., Boyle, E.A., 2015. Daily to decadal variability of size-fractionated iron and iron-binding ligands at the Hawaii Ocean Time-series Station ALOHA. Geochim. Cosmochim. Acta 171, 303-324.

Fujii, M., Dang, T., Bligh, M., Rose, A., Waite, T., 2013. Effect of natural organic matter on iron uptake by the freshwater cyanobacterium Microcystis aeruginosa. Environ. Sci. Technol. 48, 365-374.

Gerringa, L.J., Herman, P.M., Poortvliet, T.C., 1995. Comparison of the linear Van den Berg/Ruzic transformation and a non-linear fit of the Langmuir isotherm applied to Cu speciation data in the estuarine environment. Mar. Chem. 48, 131-142.

Gerringa, L.J.A., Rijkenberg, M.J.A., Thuróczy, C.E., Maas, L.R.M., 2014. A critical look at the calculation of the binding characteristics and concentration of iron complexing ligands in seawater with suggested improvements. Environ. Chem. 11, 114-136.

Gledhill, M., Buck, K.N., 2012. The organic complexation of iron in the marine en vironment: a review. Front. Microbiol. 3, 1-19.

Gledhill, M., van den Berg, C.M.G., 1994. Determination of complexation of iron(III) with natural organic complexing ligands in sea water using cathodic stripping voltammetry. Mar. Chem. 47, 41-54.

Gledhill, M., Achterberg, E.P., Honey, D.J., Nielsdottir, M.C., Rijkenberg, M.J., 2013. Distributions of particulate Heme b in the Atlantic and Southern Oceans-implications for electron transport in phytoplankton. Glob. Biogeochem. Cycles 27, 1072-1082.

Gonzalez, H.E., Smetacek, V., 1994. The possible role of the cyclopoid copepod Oithona in retarding vertical flux of zooplankton faecal material. Mar. Ecol. Prog. Ser. 113, 233-246.

Hassler, C.S., Schoemann, V., Nichols, C.M., Butler, E.C.V., Boyd, P.W., 2011. Saccharides enhance iron bioavailability to southern ocean phytoplankton. Proc. Natl. Acad. Sci. U. S. A. 108, 1076-1081.

Hassler, C.S., van den Berg, C.M.G., Boyd, P.W., 2017. Toward a Regional Classification to Provide a More Inclusive Examination of the Ocean Biogeochemistry of Iron-Binding Ligands. Front. Mar. Sci. 4.

Hogle, S.L., Barbeau, K.A., Gledhill, M., 2014. Heme in the marine environment: from cells to the iron cycle. Metallomics 6, 1107-1120.

Honey, D.J., Gledhill, M., Bibby, T.S., Legiret, F.E., Pratt, N.J., Hickman, A.E., Lawson, T., Achterberg, E.P., 2013. Heme b in marine phytoplankton and particulate material from the North Atlantic Ocean. Mar. Ecol. Prog. Ser. 483, 1-17.

Hunter, K.A., Boyd, P.W., 2007. Iron-binding ligands and their role in the ocean biogeochemistry of iron. Environ. Chem. 4, 221-232.

Hutchins, D.A., Wang, W.X., Fisher, N.S., 1995. Copepod grazing and the biogeochemical fate of diatom iron. Limnol. Oceanogr. 40, 989-994.

Hutchins, D.A., Witter, A.E., Butler, A., Luther III, G.W., 1999. Competition among marine phytoplankton for different chelated iron species. Nature 400, 858-861.

Iversen, M.H., Poulsen, L.K., 2007. Coprorhexy, coprophagy, and coprochaly in the copepods Calanus helgolandicus, Pseudocalanus elongatus, and Oithona similis. Mar. Ecol. Prog. Ser. 350, 79-89.

Jansen, S., Henjes, J., Friedrichs, L., Krägefsky, S., Bathmann, U., 2007. Fate of copepod faecal pellets during an iron induced phytoplankton bloom (EIFEX) in the Southern Ocean.

King, D.W., Metz, M., Hosmer, J., 1995. The photochemistry of iron in seawater. In: Abstracts of papers of the American Chemical Society 209, 118-GEOC.

Kondo, Y., Moffett, J.W., 2015. Iron redox cycling and subsurface offshore transport in the eastern tropical South Pacific oxygen minimum zone. Mar. Chem. 168, 95-103.

Kondo, Y., Takeda, S., Nishioka, J., Obata, H., Furuya, K., Johnson, W.K., Wong, C.S., 2008. Organic iron (III) complexing ligands during an iron enrichment experiment in the western subarctic North Pacific. Geophys. Res. Lett. 35.

Krachler, R., Krachler, R.F., Wallner, G., Hann, S., Laux, M., Cervantes Recalde, M.F., Jirsa, F., Neubauer, E., von der Kammer, F., Hofmann, T., Keppler, B.K., 2015. River derived humic substances as iron chelators in seawater. Mar. Chem. 174, 85-93.

Laglera, L.M., van den Berg, C.M.G., 2009. Evidence for geochemical control of iron by humic substances in seawater. Limnol. Oceanogr. 54, 610-619.

Laglera, L.M., Battaglia, G., van den Berg, C.M.G., 2007. Determination of humic substances in natural waters by cathodic stripping voltammetry of their complexes with iron. Anal. Chim. Acta 599, 58-66.

Laglera, L.M., Battaglia, G., van den Berg, C.M.G., 2011. Effect of humic substances on the iron speciation in natural waters by CLE/CSV. Mar. Chem. 127, 134-143.

Laglera, L.M., Downes, J., Santos-Echeandía, J., 2013a. Comparison and combined use of linear and non-linear fitting for the estimation of complexing parameters from metal titrations of estuarine samples by CLE/AdCSV. Mar. Chem. 155, 102-112.

Laglera, L.M., Santos-Echeandía, J., Caprara, S., Monticelli, D., 2013b. Quantification of iron in seawater at the low picomolar range based on optimization of bromate/ammonia/dihydroxynaphtalene system by catalytic adsorptive cathodic stripping voltammetry. Anal. Chem. 85, 2486-2492.

Laglera, L.M., Tovar-Sánchez, A., Iversen, M.H., González, H.E., Naik, H., Mangesh, G., Assmy, P., Klaas, C., Mazzocchi, M.G., Montresor, M., Naqvi, S.W.A., Smetacek, V., Wolf-Gladrow, D.A., 2017. Iron partitioning during LOHAFEX: Copepod grazing as a major driver for iron recycling in the Southern Ocean. Mar. Chem. 196, 148-161.

Laglera-Baquer, L.M., González-Dávila, M., Santana-Casiano, J.M., 2001. Determination of metallic complexing capacities of the dissolved organic material in seawater. Sci. Mar. 65, 33-40.

Liu, X.W., Millero, F.J., 2002. The solubility of iron in seawater. Mar. Chem. 77, 43-54 Maldonado, M.T., Strzepek, R.F., Sander, S., Boyd, P.W., 2005. Acquisition of iron bound to strong organic complexes, with different Fe binding groups and photochemical reactivities, by plankton communities in Fe-limited subantarctic waters. Glob. Biogeochem. Cycles 19.

Martin, J.H., 1990. Glacial-interglacial CO2 change: the iron hypothesis. Paleoceanography 5, 1-13.

Martin, P., Van Der Loeff, M.R., Cassar, N., Vandromme, P., D'Ovidio, F., Stemmann, L. Rengarajan, R., Soares, M., González, H.E., Ebersbach, F., Lampitt, R.S., Sanders, R., Barnett, B.A., Smetacek, V., Naqvi, S.W.A., 2013. Iron fertilization enhanced net community production but not downward particle flux during the Southern Ocean iron fertilization experiment LOHAFEX. Glob. Biogeochem. Cycles 27, 871-881.

Mawji, E., Gledhill, M., Milton, J.A., Tarran, G.A., Ussher, S., Thompson, A., Wolff, G.A., Worsfold, P.J., Achterberg, E.P., 2008. Hydroxamate siderophores: occurrence and importance in the Atlantic Ocean. Environ. Sci. Technol. 42, 8675-8680.

Mazzocchi, M.G., González, H.E., Vandromme, P., Borrione, I., Ribera d'Alcalà, M., Gauns, M., Assmy, P., Fuchs, B., Klaas, C., Martin, P., Montresor, M., Nagappa, R., Naqvi, S.W.A., Smetacek, V., 2009. A Non-diatom Plankton Bloom Controlled by Copepod Grazing and Amphipod Predation: Preliminary Results From the LOHAFEX Iron-fertilisation Experiment. GLOBEC International Newsletter, pp. 3-6.

Møller, E.F., Thor, P., Nielsen, T.G., 2003. Production of DOC by Calanus finmarchicus, C. glacialis and C. hyperboreus through sloppy feeding and leakage from fecal pellets. Mar. Ecol. Prog. Ser. 262, 185-191.

Monticelli, D., Dossi, C., Castelletti, A., 2010. Assessment of accuracy and precision in speciation analysis by competitive ligand equilibration-cathodic stripping voltammetry (CLE-CSV) and application to Antarctic samples. Anal. Chim. Acta 675, $116-124$.

Morrissey, J., Bowler, C., 2012. Iron utilization in marine cyanobacteria and eukaryotic algae. Front. Microbiol. 3.

Nishioka, J., Obata, H., 2017. Dissolved iron distribution in the western and central subarctic Pacific: HNLC water formation and biogeochemical processes. Limnol. Oceanogr. 62, 2004-2022. https://doi.org/10.1002/lno.10548.

Nodwell, L.M., Price, N.M., 2001. Direct use of inorganic colloidal iron by marine mixotrophic phytoplankton. Limnol. Oceanogr. 46, 765-777.

Noji, T.T., Estep, K.W., Macintyre, F., Norrbin, F., 1991. Image analysis of faecal material grazed upon by three species of copepods: evidence for coprorhexy, coprophagy and coprochaly. J. Mar. Biol. Assoc. U. K. 71, 465-480.

Pižeta, I., Sander, S.G., Hudson, R.J.M., Omanović, D., Baars, O., Barbeau, K.A., Buck, K.N., Bundy, R.M., Carrasco, G., Croot, P.L., Garnier, C., Gerringa, L.J.A., Gledhill, M., Hirose, K., Kondo, Y., Laglera, L.M., Nuester, J., Rijkenberg, M.J.A., Takeda, S., Twining, B.S., Wells, M., 2015. Interpretation of complexometric titration data: An intercomparison of methods for estimating models of trace metal complexation by natural organic ligands. Mar. Chem. 173, 3-24.

Powell, R.T., Wilson-Finelli, A., 2003. Photochemical degradation of organic iron complexing ligands in seawater. Aquat. Sci. 65, 367-374.

Rich, H.W., Morel, F.M.M., 1990. Availability of well-defined iron colloids to the marine 
diatom Thalassiosira weissflogii. Limnol. Oceanogr. 35, 652-662.

Rijkenberg, M.J.A., Gerringa, L.J.A., Carolus, V.E., Velzeboer, I., de Baar, H.J.W., 2006. Enhancement and inhibition of iron photoreduction by individual ligands in open ocean seawater. Geochim. Cosmochim. Acta 70, 2790-2805.

Rue, E.L., Bruland, K.W., 1995. Complexation of iron(III) by natural organic ligands in the Central North Pacific as determined by a new competitive ligand equilibration/adsorptive cathodic stripping voltammetric method. Mar. Chem. 50, 117-138.

Rue, E.L., Bruland, K.W., 1997. The role of organic complexation on ambient iron chemistry in the equatorial Pacific Ocean and the response of a mesoscale iron addition experiment. Limnol. Oceanogr. 42, 901-910.

Ruzic, I., 1982. Theoretical aspects of the direct titration of natural waters and its information yield for trace metal speciation. Anal. Chim. Acta 140, 99-113.

Sander, S.G., Hunter, K.A., Harms, H., Wells, M., 2011. Numerical approach to speciation and estimation of parameters used in modeling trace metal bioavailability. Environ. Sci. Technol. 45, 6388-6395.

Sarthou, G., Vincent, D., Christaki, U., Obernosterer, I., Timmermans, K.R., Brussaard, C.P.D., 2008. The fate of biogenic iron during a phytoplankton bloom induced by natural fertilisation: impact of copepod grazing. Deep-Sea Res. II Top. Stud. Oceanogr. 55, 734-751.

Sato, M., Takeda, S., Furuya, K., 2007. Iron regeneration and organic iron(III)-binding ligand production during in situ zooplankton grazing experiment. Mar. Chem. 106, 471-488.

Schulz, I., Montresor, M., Klaas, C., Assmy, P., Wolzenburg, S., Gauns, M., Sarkar, A Thiele, S., Wolf-Gladrow, D., Naqvi, W., Smetacek, V., 2018. Remarkable structural resistance of a nanoflagellate-dominated plankton community to iron fertilization during the Southern Ocean experiment LOHAFEX. Mar. Ecol. Prog. Ser. 601, 77-95.

Shaked, Y., Lis, H., 2012. Disassembling iron availability to phytoplankton. Front. Microbiol. 3.

Smetacek, V., Naqvi, S.W.A., 2008. The next generation of iron fertilization experiments in the Southern Ocean. Philos. Trans. R. Soc. A Math. Phys. Eng. Sci. 366, 3947-3967.

Smetacek, V., Naqvi, S.W.A., 2010. The Expedition of the Research Vessel "Polarstern" to the Antarctic in 2009 (ANT-XXV/3 - LOHAFEX). In: Bornemann, H. (Ed.), Berichte zur Polar- und Meeresforschung, Bremerhaven. http://hdl.handle.net/10013/epic 35169.

Smetacek, V., Scharek, R., Nöthig, E.-M., 1990. Seasonal and Regional Variation in the Pelagial and Its Relationship to the Life History Cycle of Krill, Antarctic Ecosystems. Springer, pp. 103-114.

Smetacek, V., Klaas, C., Strass, V.H., Assmy, P., Montresor, M., Cisewski, B., Savoye, N., Webb, A., D'Ovidio, F., Arrieta, J.M., Bathmann, U., Bellerby, R., Berg, G.M., Croot, P., Gonzalez, S., Henjes, J., Herndl, G.J., Hoffmann, L.J., Leach, H., Losch, M., Mills, M.M., Neill, C., Peeken, I., Röttgers, R., Sachs, O., Sauter, E., Schmidt, M.M., Schwarz, J., Terbrüggen, A., Wolf-Gladrow, D., 2012. Deep carbon export from a Southern Ocean iron-fertilized diatom bloom. Nature 487, 313-319.

Sposito, G., 1982. On the use of the Langmuir equation in the interpretation of 'adsorption' phenomena: II. The 'two-surface' Langmuir equation. Soil Sci. Soc. Am. J. 46, $1147-1152$

Strom, S.L., 1993. Production of pheopigments by marine protozoa: results of laboratory experiments analysed by HPLC. Deep-Sea Res. I Oceanogr. Res. Pap. 40, 57-80.

Strom, S.L., Morello, T.A., Bright, K.J., 1998. Protozoan size influences algal pigment degradation during grazing. Mar. Ecol. Prog. Ser. 164, 189-197.

Tani, H., Nishioka, J., Kuma, K., Takata, H., Yamashita, Y., Tanoue, E., Midorikawa, T., 2003. Iron(III) hydroxide solubility and humic-type fluorescent organic matter in the deep water column of the Okhotsk Sea and the northwestern North Pacific Ocean. Deep-Sea Res. I Oceanogr. Res. Pap. 50, 1063-1078.

Thiele, S., Fuchs, B.M., Ramaiah, N., Amanna, R., 2012. Microbial community response during the iron fertilization experiment LOHAFEX. Appl. Environ. Microbiol. 78, 8803-8812.

Thiele, S., Wolf, C., Schulz, I.K., Assmy, P., Metfies, K., Fuchs, B.M., 2014. Stable Composition of the Nano- and Picoplankton Community during the Ocean Iron Fertilization Experiment LOHAFEX. PLoS ONE 9, e113244.

Thuróczy, C.E., Gerringa, L.J.A., Klunder, M.B., Laan, P., de Baar, H.J.W., 2011. Observation of consistent trends in the organic complexation of dissolved iron in the Atlantic sector of the Southern Ocean. Deep-Sea Res. II Top. Stud. Oceanogr. 58, 2695-2706.

Tovar-Sánchez, A., 2012. Sampling approaches for trace elements determination in seawater. In: Pawliszyn, J. (Ed.), Comprehensive Sampling and Sample Preparation: Analytical Techniques for Scientists. Academic Press Elsevier, New York, pp. 317-334.

Tsuda, A., Takeda, S., Saito, H., Nishioka, J., Kudo, I., Nojiri, Y., Suzuki, K., Uematsu, M., Wells, M.L., Tsumune, D., Yoshimura, T., Aono, T., Aramaki, T., Cochlan, W.P., Hayakawa, M., Imai, K., Isada, T., Iwamoto, Y., Johnson, W.K., Kameyama, S., Kato, S., Kiyosawa, H., Kondo, Y., Levasseur, M., Machida, R.J., Nagao, I., Nakagawa, F., Nakanish, T., Nakatsuka, S., Narita, A., Noiri, Y., Obata, H., Ogawa, H., Oguma, K., Ono, T., Sakuragi, T., Sasakawa, M., Sato, M., Shimamoto, A., Takata, H., Trick, C.G., Watanabe, Y.W., Wong, C.S., Yoshie, N., 2007. Evidence for the grazing hypothesis: Grazing reduces phytoplankton responses of the HNLC ecosystem to iron enrichment in the western subarctic pacific (SEEDS II). J. Oceanogr. 63, 983-994.

Turoczy, N.J., Sherwood, J.E., 1997. Modification of the van den Berg/Ruzic method for the investigation of complexation parameters of natural waters. Anal. Chim. Acta 354, 15-21.

van den Berg, C.M.G., 1982. Determination of copper complexation with natural organic ligands in seawater by equilibration with MnO2. I. Theory. Mar. Chem. 11, 307-322.

van den Berg, C.M.G., 1984. Determination of copper in seawater by cathodic stripping voltammetry of complexes with catechol. Anal. Chim. Acta 164, 195-207.

van den Berg, C.M.G., 1995. Evidence for organic complexation of iron in seawater. Mar. Chem. 50, 139-157.

van den Berg, C.M.G., 2006. Chemical speciation of iron in seawater by cathodic stripping voltammetry with dihydroxynaphthalene. Anal. Chem. 78, 156-163.

Velasquez, I.B., Ibisanmi, E., Maas, E.W., Boyd, P.W., Nodder, S., Sander, S.G., 2016. Ferrioxamine siderophores detected amongst iron binding ligands produced during the remineralization of marine particles. Front. Mar. Sci. 3.

Vong, L., Laës, A., Blain, S., 2007. Determination of iron-porphyrin-like complexes at nanomolar levels in seawater. Anal. Chim. Acta 588, 237-244.

Wells, M.L., 2003. The level of iron enrichment required to initiate diatom blooms in HNLC waters. Mar. Chem. 82, 101-114.

Wilhelm, S.W., Trick, C.G., 1994. Iron-limited growth of cyanobacteria: multiple siderophore production is a common response. Limnol. Oceanogr. 39, 1979-1984.

Witter, A.E., Hutchins, D.A., Butler, A., Luther, G.W., 2000. Determination of conditional stability constants and kinetic constants for strong model Fe-binding ligands in seawater. Mar. Chem. 69, 1-17.

Yang, R., Su, H., Qu, S., Wang, X., 2017. Capacity of humic substances to complex with iron at different salinities in the Yangtze River estuary and East China Sea. Sci. Rep. 7 , 1381. 